\title{
Fiscal Sustainability and Hydrocarbon Endowment Per Capita in the GCC
}

\author{
Monica Malik and Thirumalai Nagesh
}

\section{INTRODUCTION}

GCC economies remain highly dependent on the hydrocarbon sector in terms of the composition of GDP and as a source of government revenue and export base. However, variations persist across the region, with the economies of Bahrain and Dubai the most diversified and Kuwait the least. The key non-oil sectors across the GCC tend to be in the following areasconstruction, real estate, tourism, retail, hospitality, aviation and petrochemical and energy-intensive industries (such as aluminium). The policy focus again intensified towards economic diversification from end-2014 with the sharp fall in the oil price. New development plans have been announced to reach this objective, most notably in Saudi Arabia, with the National Transformation Plan and Vision 2030, both announced in 2016. These plans are a blueprint to diversify the Saudi economy (fiscally and in terms of composition of GDP) and highlight the government's commitment to transform the economy away from oil.

\section{Malik $(\bowtie) \bullet$ T. Nagesh}

The Hills Compound, Abu Dhabi, United Arab Emirates

e-mail: monica.malik@adcb.com; Thirumalainagesh.Venkatesh@adcb.com

(C) The Author(s) 2021

G. Luciani, T. Moerenhout (eds.), When Can Oil Economies Be

Deemed Sustainable?, The Political Economy of the Middle East, https://doi.org/10.1007/978-981-15-5728-6_9 
In this chapter, we focus on fiscal sustainability, given the importance of fiscal policy in the GCC. Most of the hydrocarbon earnings (via nationalized companies) accrue to the regional governments who then are the main conduit for this revenue to enter the domestic economy and the central factor dominating economic activity and domestic demand. As such, governments in the GCC play a much larger role in the economy than is generally the case for other emerging market countries and are often the key employers, especially for the national population. The role of government spending is especially vital for the macro-management of the GCC economies, given their limited control of monetary policy with their currencies being pegged to the USD. We highlight that the fiscal side is just one aspect of overall economic sustainability, albeit linked to other areas. Indeed, the diversification in the economic base will support the deepening non-oil revenue. However, fiscal reforms and consolidation at times of lower oil price cycles result in weaker domestic activity, including investment (public and indirectly private) and impeding diversification plans. In this chapter, we focus on fiscal reforms between 2014 and 2018 , particularly on the UAE and Saudi Arabia as they have seen the greatest fiscal reforms during this period, though it also highlights fiscal strength and developments in other GCC countries.

Despite the renewed emphasis on shifting away from the hydrocarbon sector, the GCC countries that are currently the most resilient and best able to cope with the low oil price environment are those with large hydrocarbon reserves relative to their populations (hydrocarbon rich per capita). These countries tend to use less of their resources supporting the population, resulting in stronger fiscal fundamentals that bolster their economic sustainability despite high exposure to the hydrocarbon sector. We highlight in the chapter that the economic strength of these countries are reflected in a number of economic indicators, including low debt and high foreign currency reserves, which in turn feed into their stronger sovereign rating. This reflects their stronger saving rates when oil prices are higher, alongside lower budget breakeven oil prices. This does not mean that these economies should not look to diversify. Rather, it highlights that their fiscal strength results in less pressure on the economy during times of low prices and reform. Thus, fiscal sustainability at this stage is mostly unrelated to the degree of economic diversification. Fiscal diversification has largely been weak across the region, with hydrocarbon revenue remaining the main source of government income. That some countries have a relatively higher share of non-oil revenue in total revenue, in many cases, 
reflect weaker hydrocarbon endowment rather than a diversified revenue base (especially tax) or lower subsidy levels.

The underlying fiscal strength and sustainability of GCC economies is especially important at a time when the region has seen relatively limited success in widening the economic base (composition of GDP) much beyond pre-2014 levels. There have been some signs of greater fiscal reforms, especially in the UAE and Saudi Arabia. However, this has placed downward pressure on their economies, including the private sectorwho are often proposed key drivers of economic diversification and raising employment opportunities for nationals. Thus, government-led initiatives will be central to boosting and deepening economic activity, alongside developing a framework to access private capital and expertise-local or international. Notably, a number of GCC countries are promoting labor nationalization programs, in varying degrees, to help create job opportunities for nationals, especially the youth. Reducing the share of government spending on wages will also be critical to boosting fiscal sustainability across the GCC, especially for the hydrocarbon poorer per capita countries, alongside reforms to increase non-oil revenue.

The other area of policy adjustment and economic support has been on the oil front since 2017-the pullback in OPEC+ oil production has helped to reduce global inventories and has provided fundamental support to the oil price. The rise in global oil prices since mid-2017 reduces some of the fiscal (and external) pressure seen from end-2014, particularly in 1H2016. In turn, this has allowed an increase in government spending for 2018. GCC fiscal positions improved in 2018 despite the increase in government spending, thanks to the higher oil revenue. However, the fall in oil price at the end of 2018 and the ongoing development in hydrocarbon technology that are likely to impact future supply and demand (including shale oil, renewable energy and electric vehicles) highlight the need for further reforms to strengthen and deepen fiscal sustainability in the GCC.

\section{Variations in GCC Hydrocarbon Endowments and ECONOMic Sustainability}

The size of hydrocarbon reserves per capita is a key factor for fiscal sustainability currently rather than just the size of the hydrocarbon reserves themselves or hydrocarbon revenue as a percentage of total government 
revenue. Based on per-capita hydrocarbon endowments, the GCC countries can be broadly divided into two categories (Figs. 9.1 and 9.2):

- Hydrocarbon richer per capita: These countries have higher hydrocarbon reserves (and production) relative to their populations. They include Kuwait, Qatar and the UAE (Abu Dhabi led).

- Hydrocarbon poorer per capita: These countries have relatively smaller hydrocarbon reserves (and production) relative to their populations. They include Bahrain, Oman and Saudi Arabia. Within this group, Oman and Bahrain are in relatively weaker positions versus Saudi.

The per-capita hydrocarbon ratio is particularly important in the GCC, given the relationship between the state and citizens-that is, the social contract. In simple terms, in GCC economic frameworks, hydrocarbon revenue falls to the government (via the national oil and gas companies) and is then distributed and mobilized for the well-being of the population and country. This has also meant that there is a framework to support the citizens from cradle to grave in various ways, including covering education and healthcare, highly subsidized utility prices, land and cheap financing

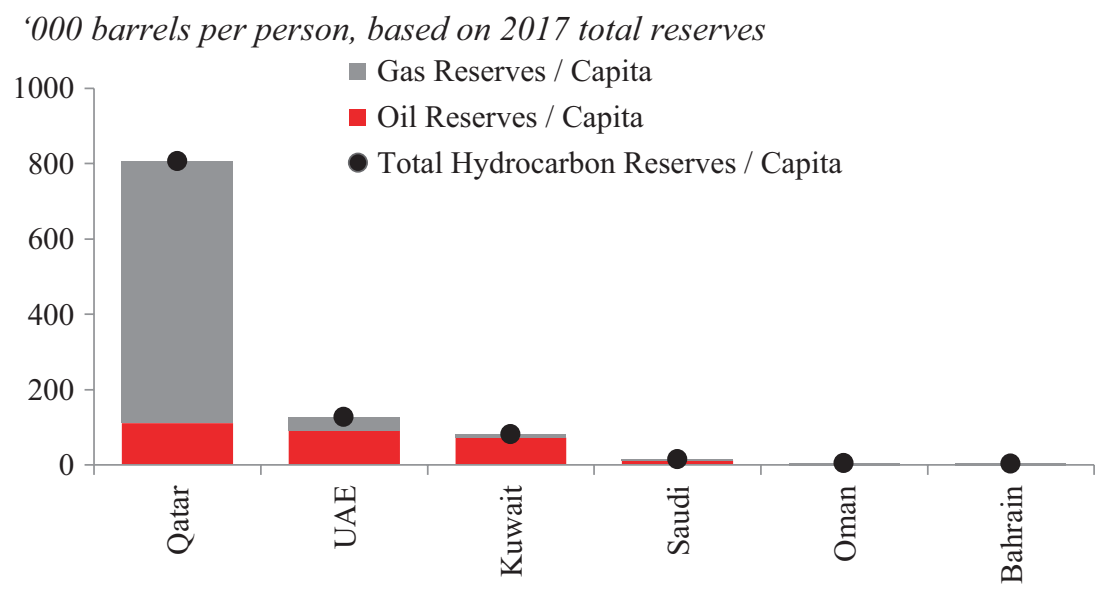

Fig. 9.1 GCC: Hydrocarbon endowment per capita (reserves) based on national population. (Source: BP [hydrocarbon reserves data], regional statistical agencies [population data 2016-18], authors' calculations and methodology) 


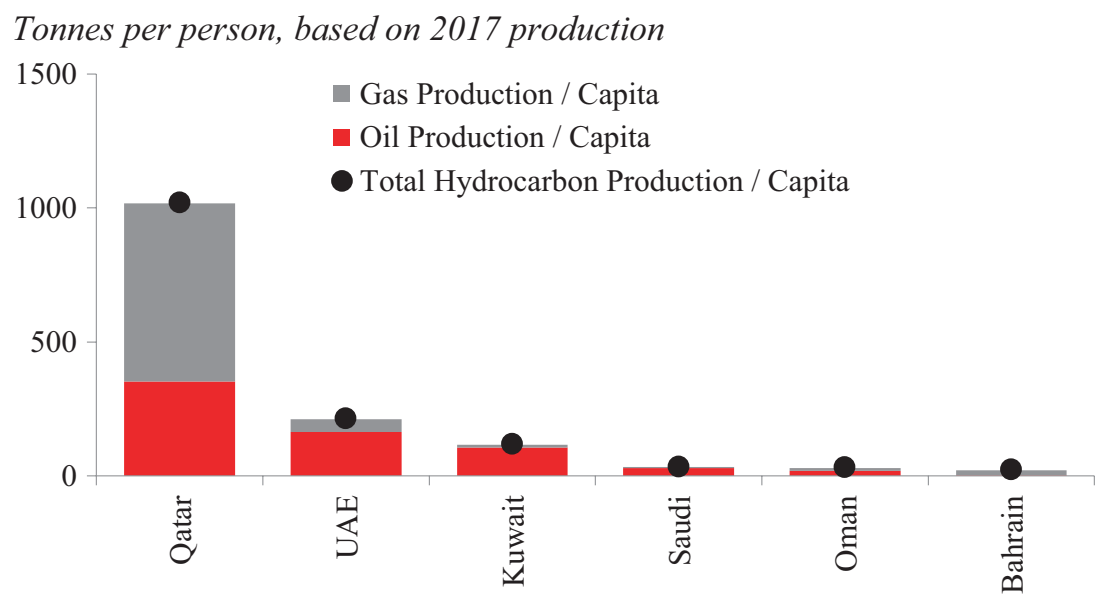

Fig. 9.2 GCC: Hydrocarbon endowment per capita (production) based on national population. (Source: BP [hydrocarbon output data], regional statistical agencies [population data 2016-18], authors' calculations and methodology)

to build housing. There are, however, variations across the region on the level of support provided by the government to nationals, including with the differences in the pace of reforms seen since 2015 also contributing to this. Moreover, the public sector has been a key employer of nationals and there has been a limited tax base. This social contract is seeing signs of change, especially with the fall in the oil price and the rise in the domestic population. Indeed, the region has seen a pullback in subsidies and the introduction of fees and some taxes since 2015. At the same time, strong population growth means that the younger generation of GCC nationals may not fully be able to rely on the state to provide them with jobs. Nevertheless, the social contract remains largely in place despite these adjustments.

The nature of the economies and impact of the social contract has resulted in hydrocarbon richer countries generally having to spend less of their hydrocarbon income to support their populations. This has also meant that these countries have seen larger fiscal surpluses and foreign currency reserve build-ups during periods of higher oil prices. Moreover, after the collapse of the oil price at end-2014, they have largely seen smaller deficits and thus, have required lesser fiscal adjustment to balance their budgets (Fig. 9.3). 
$\%$ of GDP, estimates for 2018

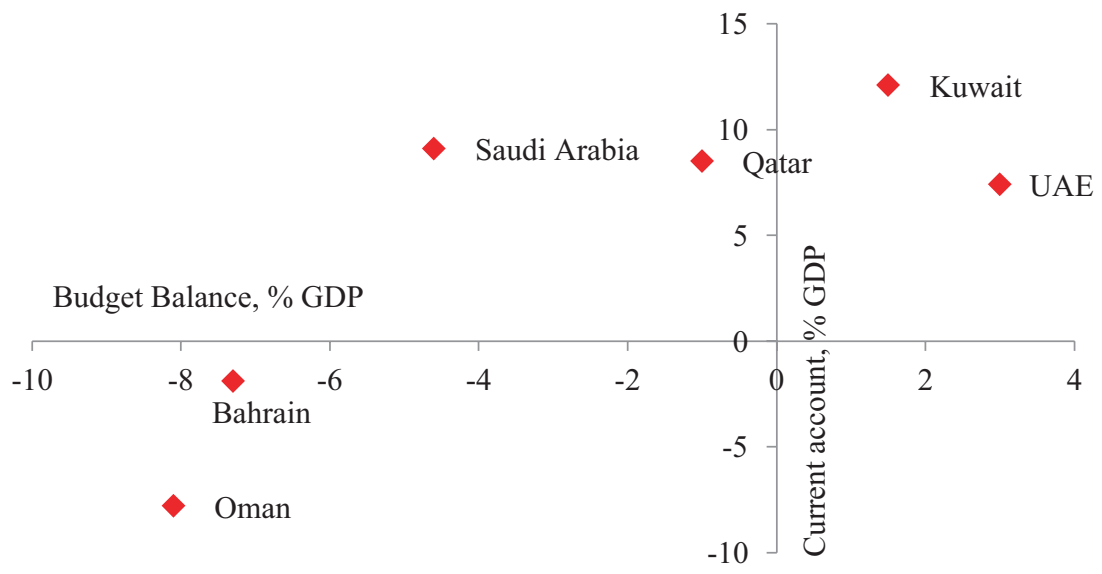

Fig. 9.3 GCC: Hydrocarbon endowment per capita reflected in current account and fiscal balances. (Source: Regional statistical agencies, ADCB estimates $[2019,25])$

\section{Hydrocarbon Endowment Seen in Various Fiscal AND ECONOMIC INDICATORS}

The hydrocarbon endowment of the GCC countries is reflected in a number of fiscal and economic indicators, including:

- Budget breakeven (BBE) oil price: This is the required oil price for a fiscal budget to be balanced. GCC budget breakeven oil prices have largely fallen since the peak in 2014 until 2017 as GCC governments reduced spending and introduced fiscal reforms. The hydrocarbon richer per capita countries have lower BBE oil prices, alongside lower external breakeven oil price (the oil price needed for the current account to be balanced). This lower BBE oil price again reflects that less of the hydrocarbon resources are spent on the national population and more of the income from resources are saved. After the 2014 shock, the UAE and Kuwait remain the most comfortable fiscally and have seen an improvement in their budgetary performance with the rise in the oil price from the oil price trough; whereas Bahrain, Oman and Saudi Arabia lagged behind. It is feasible that the $\mathrm{BBE}$ price will again rise in the future if international oil prices 
9 FISCAL SUSTAINABILITY AND HYDROCARBON ENDOWMENT PER CAPITA...

Table 9.1 GCC: Fiscal budget breakeven oil price (USD per barrel)

\begin{tabular}{lrrrrrrrrrr}
\hline & 2008 & 2009 & 2010 & 2011 & 2012 & 2013 & 2014 & 2015 & 2016 & 2017 \\
\hline Bahrain & 76 & 81 & 99 & 112 & 116 & 119 & 116 & 118 & 107 & 103 \\
Oman & 65 & 66 & 71 & 81 & 83 & 96 & 103 & 96 & 89 & 84 \\
Saudi & 57 & 65 & 67 & 78 & 79 & 92 & 106 & 95 & 96 & 78 \\
UAE & 44 & 66 & 70 & 74 & 77 & 76 & 83 & 65 & 60 & 65 \\
Qatar & 29 & 27 & 33 & 38 & 43 & 50 & 54 & 50 & 53 & 57 \\
Kuwait & 34 & 29 & 45 & 43 & 49 & 52 & 56 & 49 & 47 & 51 \\
\hline
\end{tabular}

Source: $\operatorname{IIF}(2018,3)$

recover or stabilize, and governments look to support growth and sentiment (Table 9.1).

- Debt to GDP: The hydrocarbon poorer per capita countries generally have higher government debt levels relative to GDP. The GCC countries largely entered this oil price crisis with low government debt levels (with the exception of Bahrain), as they used the strong oil prices from prior years to reduce their debt levels. Again in the case of the UAE the low overall debt position relative to GDP stems from Abu Dhabi, with Dubai seeing higher levels. However, the larger fiscal deficits in Bahrain, Oman and Saudi Arabia from 2015 with the correction in the oil price have resulted in greater funding requirements and a faster acceleration of government debt. This rise in the debt stock is resulting in more government spending being allocated to interest payments and debt servicing. For most GCC countries except Bahrain, interest payments still account for a small share of overall spending (Figs. 9.5 and 9.6).

- Foreign currency reserve position: The hydrocarbon richer per capita countries have been able to build up significant foreign currency reserves, reflecting their larger fiscal surpluses during times of higher oil prices. Moreover, there has been less pressure to draw down these reserves to cover fiscal deficits. Income from these reserves, often invested by their sovereign wealth funds (SWF), provides an additional source of income (investment) to the government and in a way is a form of revenue diversification. Saudi Arabia was looking to sell $5 \%$ of Aramco, ${ }^{1}$ in part to increase overseas investment and thereby boost and diversify government income. The

\footnotetext{
${ }^{1}$ Aramco listed its shares domestically on the Tadawul exchange on 11 December 2019, raising USD25.6 billion from a 1.5\% stake sale. Subsequently, it also exercised its "greenshoe option" to sell an additional 450 million shares, taking the total stake sale to $1.725 \%$.
} 
FX reserves, \% of 2018 GDP

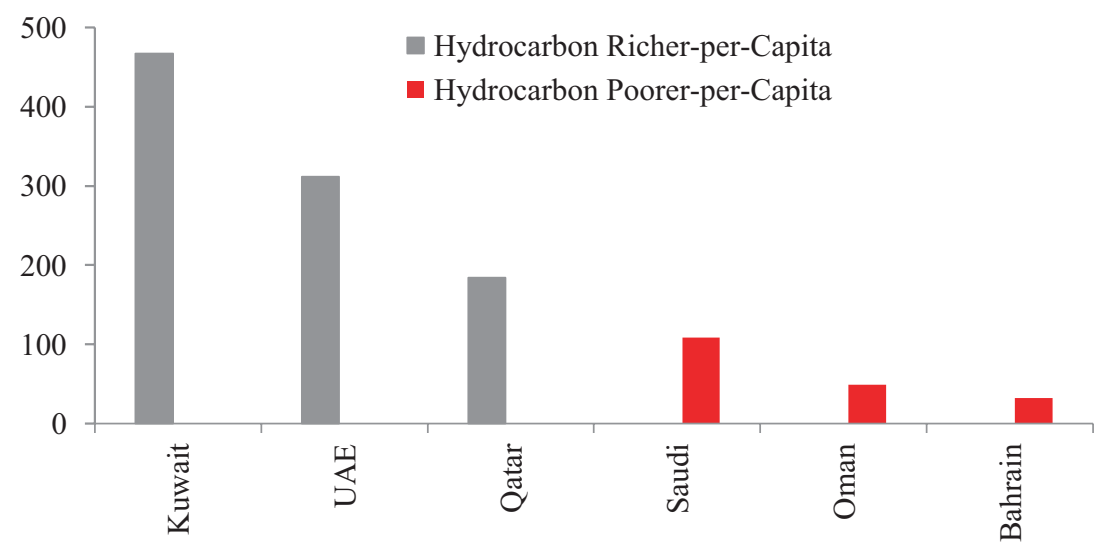

Fig. 9.4 GCC: Hydrocarbon endowment also reflected in regional FX reserve* positions. ( ${ }^{*}$ Includes reserves with SWFs and held at central banks. Source: Sovereign Wealth Fund Institute, Regional Central Banks, ADCB estimates [GDP])

Gross government debt, \% of GDP

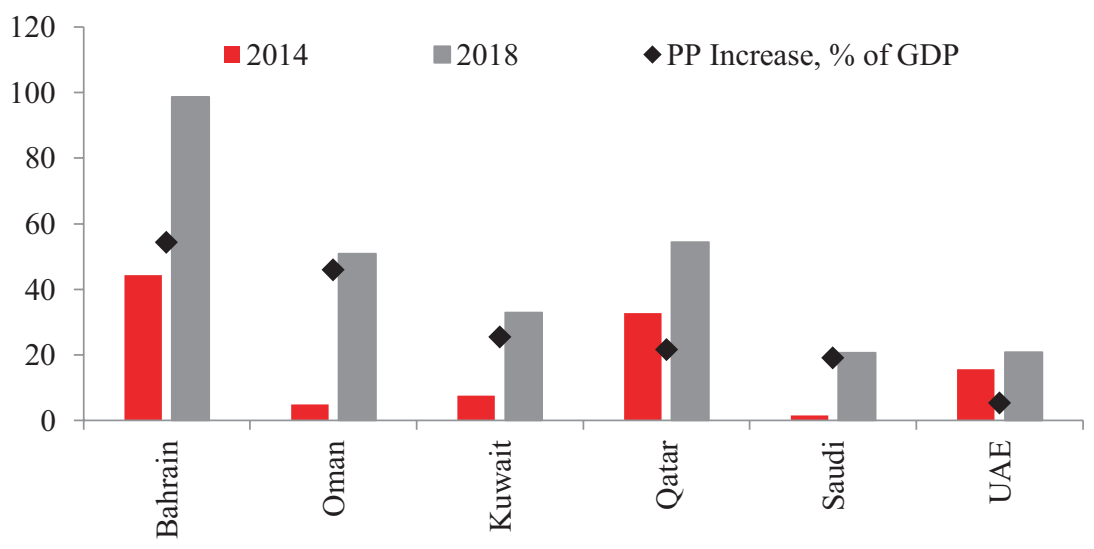

Fig. 9.5 GCC: Hydrocarbon poorer per capita countries have largely seen a faster rise in government debt. (Source: IMF, ADCB estimates) 


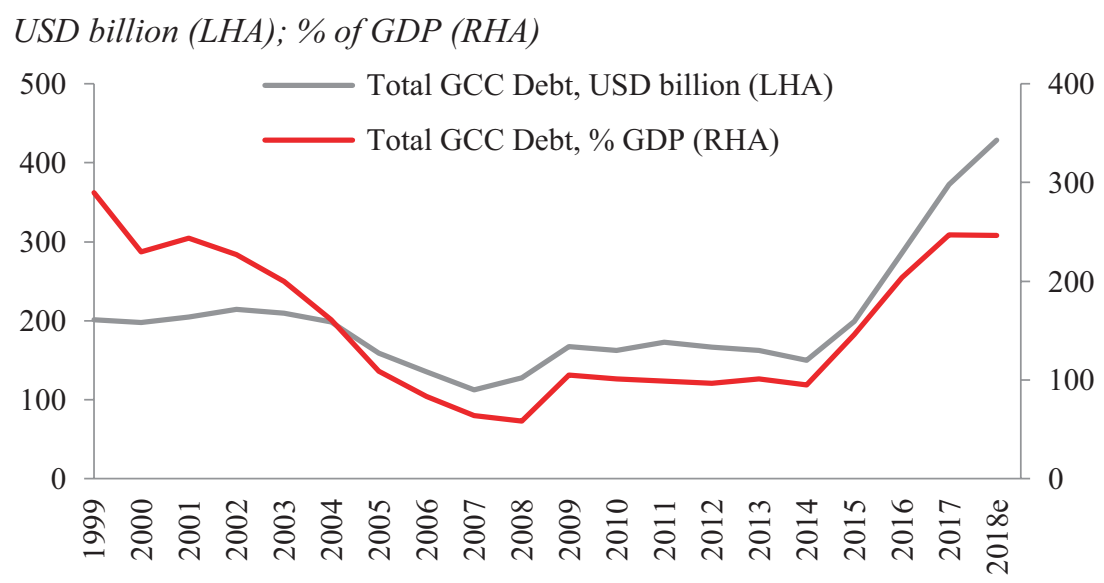

Fig. 9.6 GCC: gross government debt has risen sharply since 2014, limited fiscal space for some countries. (Source: IMF, ADCB estimates)

reduction of foreign currency reserves since 2015 is however most clearly visible in the Saudi Arabia Monetary Authority's net foreign asset (NFA) position, which highlights the drawdown in reserves to help fund the fiscal deficit. For other GCC countries, a significant part of their foreign currency reserves are held by SWFs and thus there is limited visibility (Fig. 9.4).

- Sovereign ratings: foreign currency reserve positions and government debt levels are also reflected in the sovereign ratings of GCC countries. The hydrocarbon richer per capita countries have substantially higher sovereign ratings, underpinned by large foreign currency reserves and low debt levels. Notably, despite the sharp correction in the oil price, Abu Dhabi and Kuwait have not seen any ratings downgrades by the three main ratings agencies since 2014 . Moreover, their ratings remain among the strongest globally. On the other hand, Bahrain, Oman and Saudi Arabia have seen multiple downgrades over this same period. The ratings are reflected in the cost of borrowing and the risk premium, with hydrocarbon poorer per capita countries more susceptible to changes in global sentiment 
Table 9.2 GCC: Sovereign rating changes by the main rating agencies since 2015-2018

\begin{tabular}{|c|c|c|c|c|c|c|c|c|c|}
\hline & Fitch & & & Moody's & & & SéP & & \\
\hline & $\begin{array}{l}\text { Mid- } \\
2014\end{array}$ & Current & Change & $\begin{array}{l}\text { Mid- } \\
2014\end{array}$ & Current & Change & $\begin{array}{l}\text { Mid- } \\
2014\end{array}$ & Current & Change \\
\hline Bahrain & $\mathrm{BBB}$ & BB- & $\begin{array}{l}4 \\
\text { notches } \\
\text { down }\end{array}$ & $\mathrm{Baa} 2$ & B2 & $\begin{array}{l}6 \\
\text { notches } \\
\text { down }\end{array}$ & $\mathrm{BBB}$ & $\mathrm{B}+$ & $\begin{array}{l}5 \\
\text { notches } \\
\text { down }\end{array}$ \\
\hline Kuwait & AA & $\mathrm{AA}$ & $\begin{array}{l}\text { No } \\
\text { change }\end{array}$ & $\mathrm{Aa} 2$ & $\mathrm{Aa} 2$ & $\begin{array}{l}\text { No } \\
\text { change }\end{array}$ & AA & AA & $\begin{array}{l}\text { No } \\
\text { change }\end{array}$ \\
\hline Oman & -NA- & $\mathrm{BB}+$ & $\begin{array}{l}2 \\
\text { notches } \\
\text { down }{ }^{\mathrm{a}}\end{array}$ & $\mathrm{Al}$ & $\mathrm{Bal}$ & $\begin{array}{l}6 \\
\text { notches } \\
\text { down }\end{array}$ & A & $\mathrm{BB}$ & $\begin{array}{l}6 \\
\text { notches } \\
\text { down }\end{array}$ \\
\hline Qatar & $\mathrm{AA}^{\mathrm{b}}$ & AA- & $\begin{array}{l}1 \text { notch } \\
\text { down }\end{array}$ & $\mathrm{Aa} 2$ & Aa3 & $\begin{array}{l}1 \text { notch } \\
\text { down }\end{array}$ & AA & $\mathrm{AA}-$ & $\begin{array}{l}1 \text { notch } \\
\text { down }\end{array}$ \\
\hline $\begin{array}{l}\text { Saudi } \\
\text { Arabia }\end{array}$ & AA & $\mathrm{A}+$ & $\begin{array}{l}2 \\
\text { notches } \\
\text { down }\end{array}$ & Aa3 & $\mathrm{Al}$ & $\begin{array}{l}2 \\
\text { notches } \\
\text { down }\end{array}$ & $\mathrm{AA}-$ & A- & $\begin{array}{l}3 \\
\text { notches } \\
\text { down }\end{array}$ \\
\hline UAE & -NA- & -NA- & -NA- & $\mathrm{Aa} 2$ & $\mathrm{Aa} 2$ & $\begin{array}{l}\text { No } \\
\text { change }\end{array}$ & -NA- & -NA- & -NA- \\
\hline $\begin{array}{l}\text { Abu } \\
\text { Dhabi }\end{array}$ & AA & $\mathrm{AA}$ & $\begin{array}{l}\text { No } \\
\text { change }\end{array}$ & $\mathrm{Aa} 2$ & $\mathrm{Aa} 2$ & $\begin{array}{l}\text { No } \\
\text { change }\end{array}$ & AA & AA & $\begin{array}{l}\text { No } \\
\text { change }\end{array}$ \\
\hline
\end{tabular}

Source: Bloomberg

a 2 notches down from 3 Jan 2017

batings started from 3 June 2015

and dependent on capital inflows (to cover fiscal and current account shortfalls and to support investment and diversification programs) (Table 9.2).

- GDP per capita and unemployment: Reflecting the fact that fewer resources in relative terms have to be used to support their populations, the hydrocarbon richer per capita countries also tend to have higher GDP per capita and spending power. Moreover, unemployment levels for nationals tend to be lower, though regional data on this front is limited. The hydrocarbon richer countries also tend to have a larger share of expatriates in their populations, given their relatively smaller national populations relative to economy size and the ability of the public sector to employ nationals. 
There are, naturally, variations within the GCC based on government policy and effectiveness. During times of high oil prices, Kuwait saw substantially larger fiscal surpluses as a percentage of GDP (2005-2008), as the government made limited progress in its investment plans, partly due to the difficult relationship between the cabinet and the National Assembly. Meanwhile, in the case of Qatar, government debt was higher at end-1990, reaching $74.4 \%$ of GDP in 1999 , given borrowing to develop the gas industry. However, the rise in gas income resulted in a sharp reduction in government debt to $8.9 \%$ of GDP in 2007 , and FX reserves rose. As noted earlier, GCC countries used strong oil revenues in 2002-2014 to reduce debt levels, though aggregate government debt have risen from 2014 to well above the 2002 peak in absolute terms, largely driven by the hydrocarbon per capita poorer countries. Notable, Saudi Arabia started issuing external debt from end-2016, earlier all of the government debt was SAR denominated.

\section{Fiscal Reform Momentum}

The period between 2003 and 2014 generally saw strongly expansionary government spending from the GCC countries. This pickup in government was supported by the strengthening in the oil price from around 2002, though the pace of spending increase also varied between the GCC countries. For example, Saudi Arabia initially took a more cautious approach, whilst focusing on reducing government debt levels. Notably, this debt repayment also supported liquidity in the banking sector (with all government debts being domestic at this point, including those held by banks and pension organizations), indirectly providing a boost to economic activity. Much of the initial increases in spending during this period was led by UAE (Dubai) and Qatar (including the development of the gas sector) and partly debt led, though with the broader pace rising across the GCC from around 2003.

The increase in government spending until 2011 was both on the current and the capital fronts, though overall the capital expenditure had limited impact in broadening the economic base. In many cases, a significant part of the investment was to upgrade infrastructure, compensating for weak periods of investment in the 1980s and 1990s with low and volatile oil prices, and for the rise in population. However, we also note that, in many cases, higher investment spending was implemented by government related entities (GREs), and thus not reflected in the governments' 
budgets. From 2012, there was a shift across the GCC toward current expenditure, likely impacted by the MENA Arab Spring developments. The overall rise in government spending was reflected in the rise in the BBE oil price of the GCC countries from 2004 to a peak in 2014, and supported by the overall rise in the oil price (ex-2009). GCC countries largely saw fiscal surpluses over this period (ex-2009), with the exception of Bahrain, which saw a sustained deficit since 2009. However, with the sharp correction in the oil price from end-2014, the focus of fiscal policy shifted towards retrenchment and reform (Figs. 9.7 and 9.8).

Since end-2014, the pace of fiscal reform in the GCC has gathered momentum. This is especially important, given (1) the large youth population and national population growth rates and (2) medium- to longterm structural challenges to the oil price, including from new technology (shale, renewable energy sources). GCC economies will have to create jobs to cater for the entry of nationals into the work force (please see our labor market and reform chapter), with educational reforms also vital for supporting the needs of the private sector and economic development. Without this job creation, greater pressure will fall on the governments to support the national populations, through jobs creation or by a support framework.

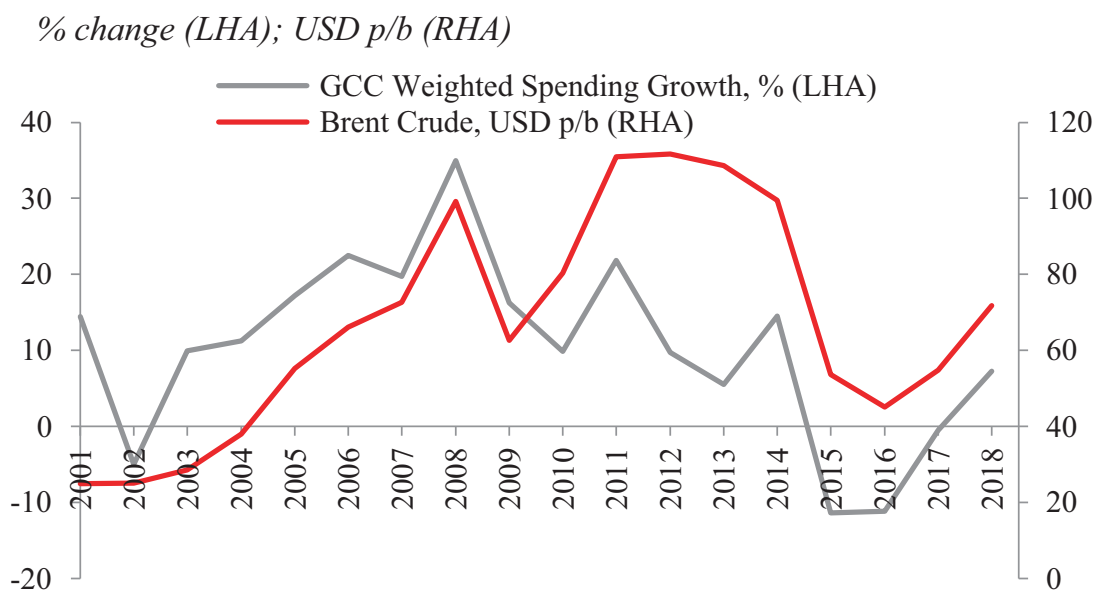

Fig. 9.7 GCC: Government spending growth was strong between 2003 and 2014. (Source: Reuters (oil price), spending growth calculated from regional statistical agencies and IMF GDP data) 
PP contribution to change in total GCC aggregate spending growth

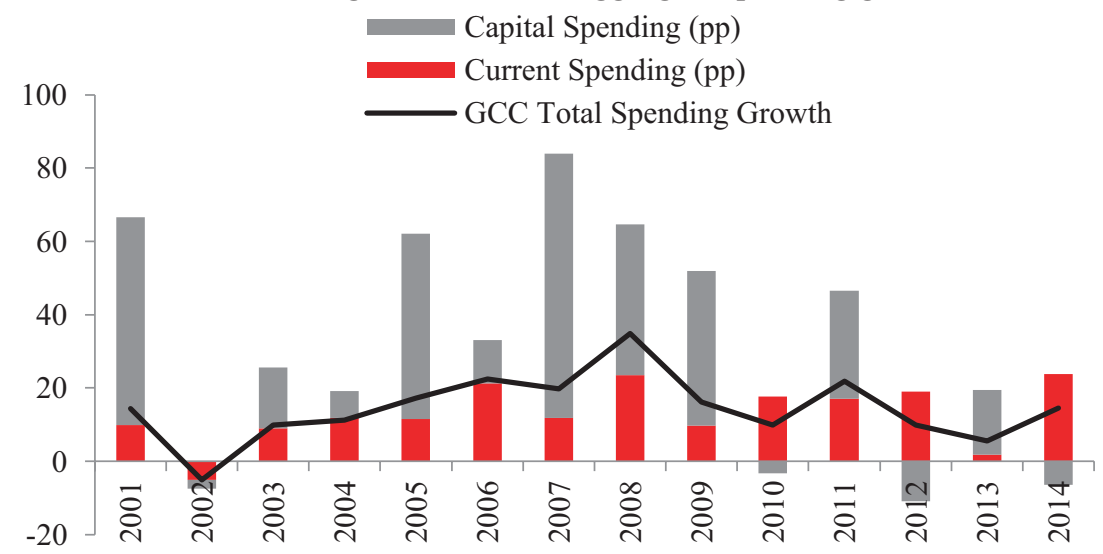

Fig. 9.8 GCC: Drivers of total GCC spending growth, by capital and current expenditure. (Source: Calculated from regional statistical agencies and IMF GDP data)

The fiscal reforms have been much wider than seen in previous oil price downturns, indicating that areas that were previously seen as sensitive are open to change and reform. For example, subsidies have been reduced, which was not the case in the 1980s and 1990s, when the main fiscal adjustment was through the retrenchment of spending. A significant development for the GCC was the introduction of VAT in Saudi Arabia and the UAE on 1 January 2018 and in Bahrain in January 2019. This was a vital initial step in developing tax revenue in the region, which has a weak tax base.

\section{Phases in GCC Fiscal Reform}

The pace and focus of fiscal consolidation across the GCC has varied over the past few years. For the main fiscal reform measures introduced, please see Appendix A. 


\subsection{Phase 1: Expenditure Cutbacks and Subsidy Reforms in 2015 and 2016}

The initial response by governments was to substantially cut back government expenditure, especially on the capital front. It is generally harder to retrench current expenditure in the GCC, given the dominance of public sector wages. Weighted GCC government expenditure fell by c.11.4\% in 2015 and by a further 11.1\% in 2016. In 2015, Kuwait, Saudi Arabia and the UAE saw a double-digit contraction in government spending. Between 2014 and 2018, Qatar and Kuwait saw a significant pullback in government spending. The UAE drop was the least among the hydrocarbon richer per capita countries, as Dubai adopted an expansionary fiscal position, whereas Abu Dhabi actually was particularly proactive in cutting government spending. The hydrocarbon richer per capita countries are generally in a stronger position to reduce government spending as a lower amount of total expenditure goes on public sector wages, reflecting the difficulties in cutting this key component of current expenditure. Nevertheless, Saudi Arabia and Oman also saw a significant retrenchment in total expenditure during this period, with only Bahrain seeing limited pullback in expenditure during this period (Figs. 9.9 and 9.10).

PP contribution to change in government spending

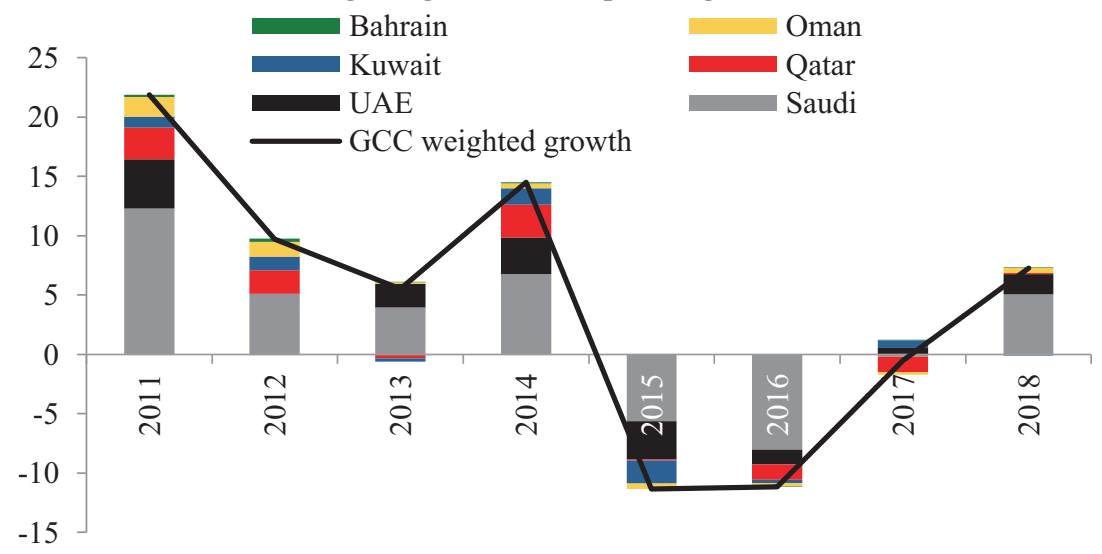

Fig. 9.9 GCC: Government sharply pulled back spending in 2015 and 2016 in response to the lower oil price. (Source: Calculated from regional statistical agencies and IMF data) 


\section{$\%$ change}

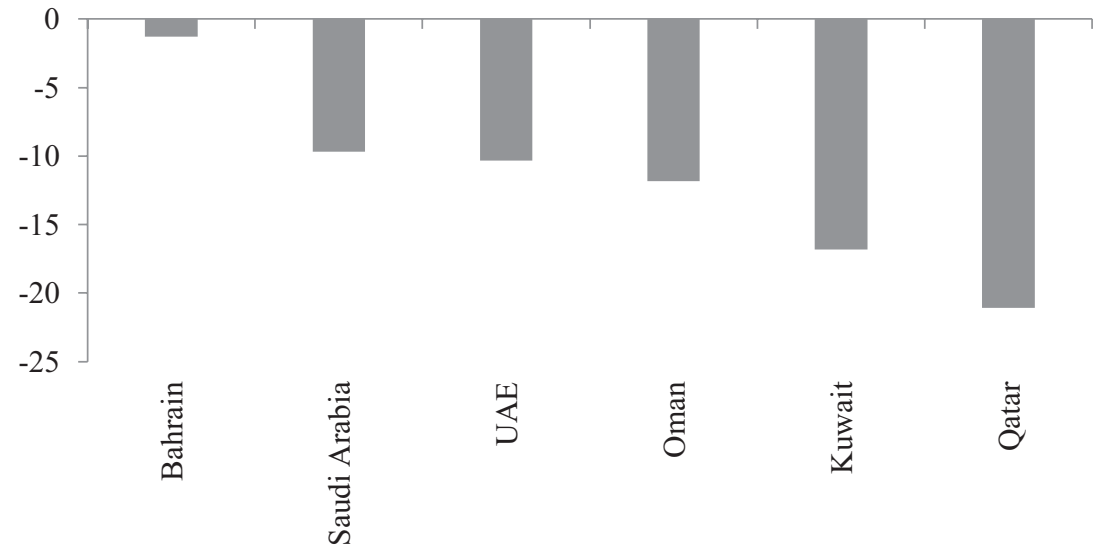

Fig. 9.10 GCC: Change in government spending from 2014 to 2018. (Source: Calculated from regional statistical agencies and IMF data)

Alongside a direct pullback in government spending, GCC governments also adopted wider measures to strengthen their fiscal positions. First, a number of countries have also focused on streamlining government related entities (GRE), so as to reduce costs and potentially increase returns for the government. This has included job cuts alongside mergers amongst entities in similar economic areas. The objective is to boost efficiencies and extract cost synergies. This trend was most visible in Abu Dhabi, where mergers were seen in a number of areas including amongst banks and companies in the hydrocarbon sector. In Abu Dhabi, there have also been signs that GREs have had to become more reliant on raising their own funding or unlocking value of their assets to meet spending and development plans, thereby reducing the support required from the central government. A later example of this is the part privatization of ADNOC distribution in December 2017. In Qatar, the rationalization included reducing the GRE workforce, with Qatargas and RasGas also merging. The new entity, called Qatargas, started operations on 1 January 2018. There were wider adjustments, with a number of the major GCC corporates having some form or degree of government ownership, including national oil companies, national utilities companies, telecoms operators, chemicals or real estate firms. 
Second, there were also increases in a number of government fees and the introduction of new ones. Importantly, progress was made on subsidy reforms - which is vital to improving fiscal sustainability, especially as the marginal ability to reduce spending moderate after the first few years. Subsidy reforms have mostly centered on rising fuel and utility prices, with the UAE kicking off the process in 2015 after some earlier price adjustments in the UAE and Qatar. Notably, these reforms have impacted nationals as well as expatriates, alongside corporates. UAE and Saudi Arabia have made some significant reductions in their subsidy framework, whilst Kuwait has seen limited reforms with ongoing opposition from the National Assembly. See Moerenhout in this volume for a detailed overview of energy subsidy reforms.

Third, there were moderate labor sector reforms. In a significant move, Saudi Arabia moved to reduce public sector wages and benefits in October 2016. This was notable, as reducing public sector wages had been/is seen as socially sensitive, especially, given the greater proportion of nationals working in the public sector versus the private. However, these were fairly short-lived.

\subsection{Phase 2: Reduction in Pace of Reform in 2017; Stabilization in Spending}

The pace of fiscal reform moderated markedly in 2017, which partly highlights reform fatigue and the difficulty of sustaining a multi-year reform program, in our view (Fig. 9.11). The weakening in economic momentum as a result of fiscal adjustments limited the ability of the economy to absorb new measures. This is particularly magnified in the GCC by the dominant role of the government in driving economic activity. Notably, a critical factor supporting the more gradual pace of fiscal adjustment in 2017 was a rise in the oil price, especially in $2 \mathrm{H} 2017$. Central to this was the change in OPEC's oil policy from one of increasing oil production to increase market share (2015 and 2016) to one of cutting output to help reduce the global oversupply and push up the price. The non-OPEC countries involved in this deal included Oman and Bahrain, alongside large global producers, such as Russia. Compliance was strong in 2017, in a large part due to greater-than-required production cuts from Saudi Arabia.

Most of the narrowing in GCC deficits in 2017 was largely due to higher oil revenue, albeit overall spending was also restrained and the pace of fiscal reform slowed. Weighted GCC fiscal spending was virtually flat in 


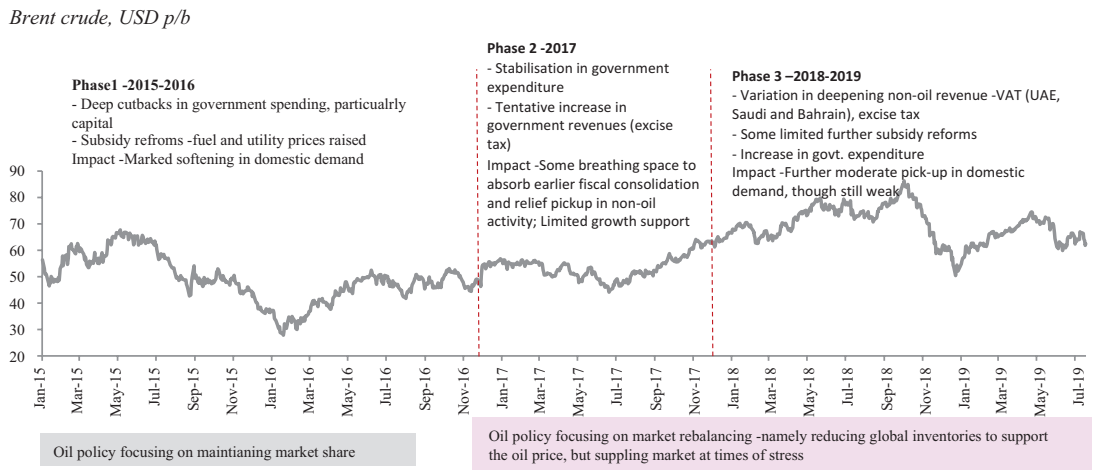

Fig. 9.11 GCC: Phases of fiscal reforms relative to oil price developments and policy. (Source: Reuters (oil price), authors' assumptions)

2017 , rising by a modest $0.9 \%$. This spending growth calculation is based on delayed payments from previous years made by Saudi Arabia government contractors in end-2016 (around SAR80 billion) being included in the 2016 fiscal accounts, alongside for "surplus projects" (SAR25 billion) (Kingdom of Saudi Arabia 2016a, 14).

There were some limited new fiscal reforms, including the introduction of an excise tax on harmful goods (cigarettes, sugary and energy drinks) in Saudi Arabia (June) UAE (October) and Bahrain (December). Kuwait and Oman also reduced water and electricity subsidies in 2017, aimed at certain sectors (Appendix A). Saudi Arabia did not progress with further subsidy reforms that were planned for the year under its Fiscal Balance Program 2020 (Kingdom of Saudi Arabia 2016b, 38). These included linking electricity $100 \%$ to reference prices and raising gasoline and diesel prices. Both were initially planned for mid-2017. Overall, there were limited major fiscal reforms in 2017.

There were however also some reversals of earlier reforms. In Saudi Arabia, public sector wages and benefits introduced in October 2016 were reversed (April 2017). A decree reinstated all allowances, financial benefits and bonuses to public employees and military staff. Moreover, a twomonth salary bonus for forces fighting on the frontline in Yemen was announced. Moreover, in December 2017, the government pushed out its balanced budget target to 2023 from the 2020 date initially set in the Fiscal Balance Program 2020 (Kingdom of Saudi Arabia 2017, 5). This 
allows more time to introduce reforms as well as to generate greater government expenditure. Subsidy price reforms (including fuel, gas for industry and utility prices) will be stretched over a longer period, with adjustments occurring until 2025 to reach international levels.

\subsection{Phase 3: Shift to Expansionary Fiscal Stance from 2018; Introduction of VAT}

After years of fiscal reforms that have placed downward pressure on economic activity, GCC governments' priorities started showing some signs of shifting to supporting growth from 2018 on. The fiscal budgets for 2018 indicated a clear shift towards expansionary spending stances to support economic activity. The stronger oil price outlook for 2018 supported the higher government spending, requiring a weaker magnitude of overall fiscal adjustment (expenditure and reforms combined). We estimate that aggregate government spending rose to $7.2 \%$ in 2018 , though again there were variations is the rise in expenditure across the region. Saudi Arabia particularly saw a significant increase, with total spending rising by $10.8 \%$ in 2018. Most of the marked fiscal improvement in 2018 in the GCC fiscal positions was largely due to higher hydrocarbon revenues and GCC fiscal positions strengthened despite the pickup in government spending.

Most of the fiscal reforms across the GCC focus on deepening non-oil revenue (Figs. 9.12 and 9.13), while raising government expenditure to support economic activity and meet wider medium-term economic goals, including diversification. Nevertheless, the reform measures were more generally periodic with differences between countries. The most significant and coordinated policy was between Saudi Arabia and the UAE with the introduction of VAT. Moreover, Saudi Arabia and Bahrain also implemented another round of energy subsidy reforms. There have been some relatively small moves to boost non-oil revenue, including raising the cost of government fees and introducing new ones. As noted earlier, some GCC countries (Bahrain, Saudi Arabia and UAE) have introduced an excise tax on harmful goods, such as tobacco and sugary drinks. There have only been limited attempts at tax reform across the region, with only Oman making some progress. Oman raised the corporate tax rate from $12 \%$ to $15 \%$ for all companies in February 2017, eliminating the exemption on the first OMR 30,000 of taxable profits that was previously in place. Oman also sold $10 \%$ stake on the Khazzan gas field at the end of 2018 to Malaysia's Petronas, as a way to raise revenue. 
$\%$, of non-oil GDP (2015)

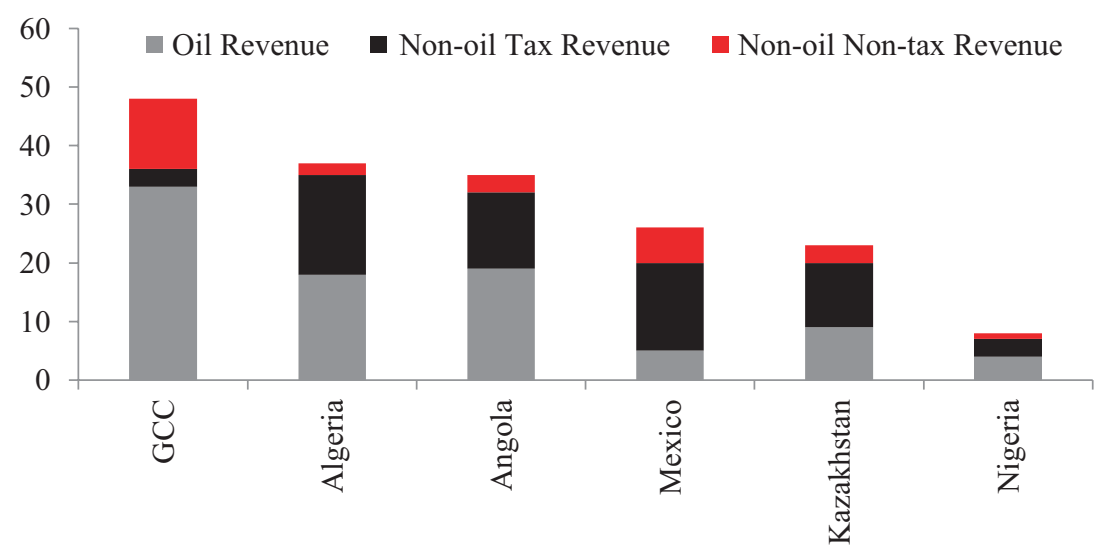

Fig. 9.12 Global: GCC countries more reliant on hydrocarbon revenues than other commodity producers. (Source: IMF $[2016,9]$ )

$\%$, hydrocarbons as a \% of total government revenue

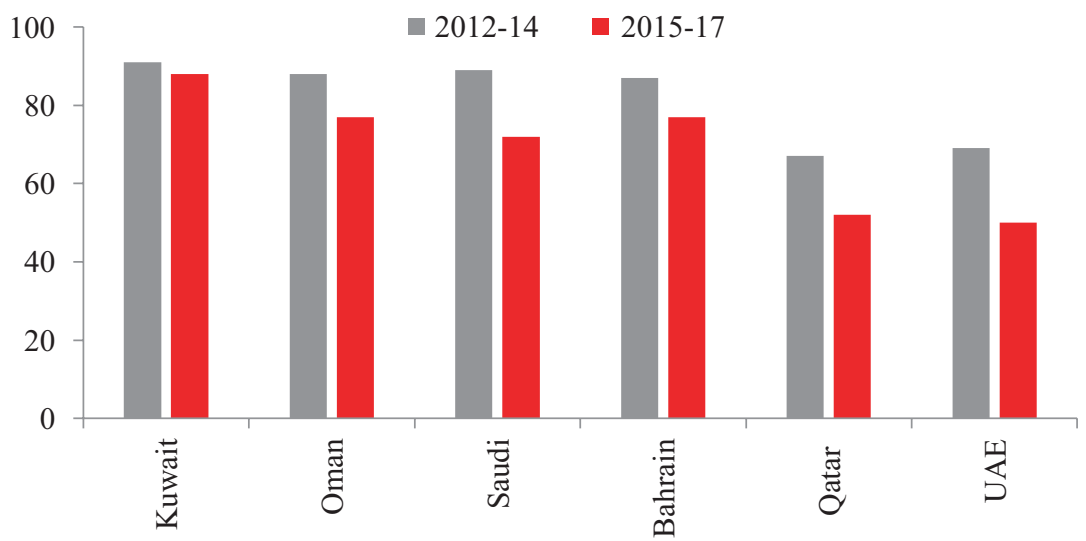

Fig. 9.13 GCC: Hydrocarbon earnings still dominate revenues; Kuwait and Bahrain see smallest reduction. (Source: Calculated from regional statistical agencies and IMF data) 


\subsection{VAT Introduction, the Main Reform in Phase 3}

The introduction of VAT is a highly positive development toward deepening and diversifying government revenues and deepening taxable income. The weak tax across the GCC has been a central factor for hydrocarbon revenue's dominance of total revenue despite the recent moves to reduce subsidies and broaden and increase government fees. The GCC states depend on hydrocarbon revenues more than other high commodityexporting economies, with hydrocarbon revenues still accounting for between $50-85 \%$ of total revenues despite the fall in the oil price. We believe that the $5 \%$ standard VAT rate has been set to balance raising government revenue with limiting downside pressure on economic activity (by dampening domestic demand). The $5 \%$ rate is low on a global basis. The average VAT rate globally is c. $15 \%$, with most countries having seen a rise in their VAT rates over time.

The UAE raised AED27 billion in revenue from VAT in 2018 - equivalent to around $1.8 \%$ of GDP. ADCB estimated that Saudi Arabia should have raised c.1.5-1.6\% of GDP in the first year of its VAT introduction (ADCB 2017, 1). ADCB noted that the UAE and Saudi Arabia will likely see the greatest proportional revenue generation in the GCC. In the case of the UAE, this reflects the larger share of private consumption in the economy. Meanwhile, Saudi Arabia has implemented a broad VAT base aimed at maximizing revenue from the new tax, including in areas such as private education and healthcare. Revenue raised by VAT is expected to increase from the second year as private consumption normalizes.

Whilst the introduction of VAT in the GCC was meant to be coordinated to avoid competitive distortions across the region, there are indications that other GCC countries could see delays. Under the Unified VAT Agreement, which outlines a common framework, other GCC countries have 12 months to introduce the tax once the first two have done so. Indeed, by the time of publishing, only Bahrain had introduced VAT in January 2019 linked to its Fiscal Balance Program, which was announced in October 2018 and aims to balance the fiscal budget by 2022. The fiscal program is vital for the GCC five-year support package for Bahrain. However, indications suggest the VAT base is likely to have been narrower than those in UAE and Saudi Arabia, with more areas being zero-rated. For example, oil products would be exempt from VAT in Bahrain.

In Kuwait, the National Assembly's budget committee announced in May 2018 that the government will postpone the implementation of VAT until 2021. Finance minister Nayef al-Hajraf noted in an interview that 
the government is facing opposition from parliament to VAT (Bloomberg 2018). Qatar has as yet given no indication as to when it plans to implement the indirect tax despite having made solid progress with the framework in 2017. Meanwhile, Oman has announced that it will postpone introduction until 2021, as outlined in the July 2019 Government of Oman bond prospectus (Reuters 2019). Earlier indications suggested that Oman will likely introduce a narrow VAT base that will exclude areas such as food, included in Saudi Arabia and the UAE (ADCB 2018, 9).

\subsection{Measures to Support Growth}

However, Saudi Arabia and UAE both introduced measures in 2018 to bolster economic activity, which had been impacted by the fiscal policy. In the UAE, a number of wider factors were also acting as headwinds to the non-oil sectors, including the indirect impact of fiscal reforms in other countries contributing to weak external demand. We believe that the direct support in Saudi Arabia was much greater in 2019, with the measures introduced largely cancelling the fiscal reforms (VAT, subsidy reductions, rise in expatriate fees, etc.). On an individual household basis, we believe that some will not be fully insulated from the impact of fiscal reforms, particularly those working in the private sector and expatriates. In the case of the UAE, the support measures were wider based (i.e. rather than fiscal based), including changes to investment regulation. Thus, we believe that the UAE likely saw fiscal consolidation in 2018 with the introduction of VAT, while in the case of Saudi Arabia it was largely offset by the higher government spending.

In the case of Saudi Arabia, a public sector support package was announced in early January, just days after the introduction of VAT and the reduction in electricity and fuel tariffs. The one-year package was aimed at reducing the burden of the fiscal reforms implemented, with a number of corporates following the government by temporarily boosting wages for some nationals including Aramco and SABIC. The support package included a cost of living allowance and bonus for civil servants and military personnel (see later for more details). Thus the overall effect of the government's fiscal reforms measures in 2018 was muted by the measures that it introduced to shield the national population from the introduction of VAT and lower subsidies. Alongside the handout package, Saudi Arabia also introduced a Citizens Account Program-transfers to support low- and middle-income families-introduced in end December 
2017. The program eventually developed into a comprehensive social security platform. Notably, the public sector handout package was extended for a further year and will also be paid in 2019. The preliminary data for 2018 indicated that the government's current expenditure (which includes wages) rose by a significant $14.3 \%$ in 2018 , up SAR103.2 billion. Investment spending contracted by SAR2.6 billion in 2018 , down $-1.2 \%$ (Fig. 9.14).

In the case of the UAE, a number of economic support packages were announced in mid-2018-on both a country-wide and emirate levelswith additional details being announced subsequently. The support packages look to (1) reduce short-term pressure on corporates; (2) boost the competitiveness of the economy; (3) structurally strengthen the business environment and raise investment levels (domestic and international); and (5) support human capital development and accumulation, amongst others. On a country-wide basis, there have been announcements related to changes to residency and investment laws, including lengthening residency visas for up to 10 years for professionals in key sectors and for foreign investors establishing businesses in the country. Moreover, companies will be allowed to own $100 \%$ of their business outside free trade zones (the current limit is $49 \%$ ) in certain sectors. The various packages also had a number of measures on the fiscal side, inclusive of reductions in fees for government services (Abu Dhabi and Dubai), alongside the outlook for higher spending in areas, such as housing, roads, infrastructure and

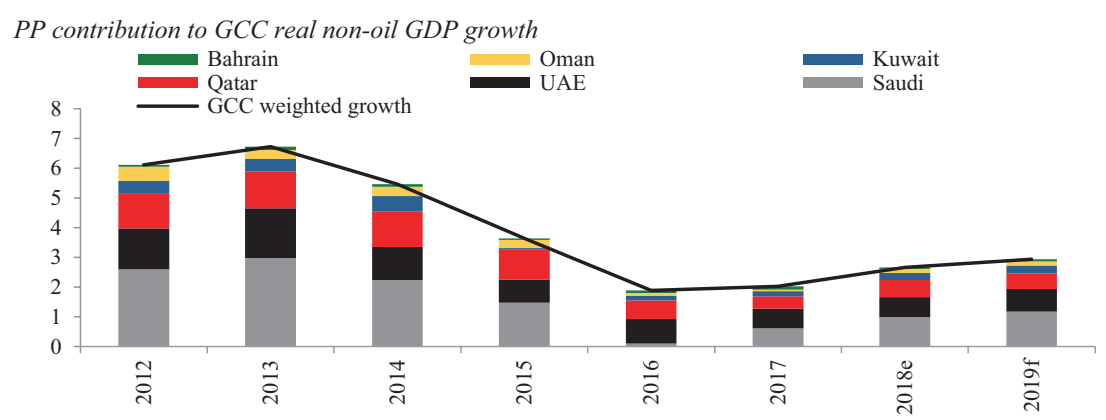

Fig. 9.14 GCC: Gradual recovery in real non-oil GDP growth from 2017 with modest pickup in government spending and more limited fiscal reforms. (Source: Calculated from regional central banks, statistical agencies and IMF data, ADCB estimates $(2019,4))$ 
healthcare. For more details of the measures introduced to support economic activity, please see Appendix B. There have been more announcements related to these measures in 2019 , either providing more details or broadening the measures.

Fiscal developments in 2019 so far indicate an overall continuation in the 2018 fiscal stance, that is, one of expansionary spending stance, measures to support growth, with limited fiscal reforms in 2019, as governments continue to look to support their respective countries' growth outlook over further fiscal consolidation. A number of countries announced expansionary budget, with the UAE and Saudi budgets pointing to the greatest planned increase in spending. Data showed that total government spending in Saudi expanded by 8.5\% in 1Q2019. Fiscal reforms in 2019 have remained patchy and relatively limited-such as the introduction of an excise tax in Qatar and Oman, rise in water prices in Oman and higher expat levies (individuals and corporates) in Saudi Arabia. However, the Saudi government announced a relief scheme for some companies to ease the impact of rising labor costs in February 2019. Saudi Arabia also announced new retail fuel prices for 2Q2019 (effective 14 April), with Aramco announcing that retail fuel prices will be set on a quarterly basis, subject to crude oil export prices. The only key exception where we expect to see rising fiscal consolidation and reforms is Bahrain, linked to its medium-term fiscal adjustment program. Meanwhile, OPEC+ countries again decided to cut output from January 2019 to support the oil price, with the production targets extended from July 2019. Nevertheless, the ability to loosen fiscal policy remains limited with the current oil price, though with the variations linked to the hydrocarbon endowment and the BBE oil price.

\section{Greatest Adjustment by Country}

Alongside the variations in the timeline of reforms, there has been varying progress in the pace of reform across the GCC as well. The UAE and to a lesser degree Saudi Arabia have been the most proactive in introducing fiscal reforms. This reflects that other economic, social and political factors are important for the ability of regional governments to progress with fiscal reforms. However, we believe that hydrocarbon endowment will likely play a strong role, especially in terms of implementing a multi-year reform program. Factors likely contributing include the variations in GDP per 
capita amongst the national population across the region and their ability to absorb fiscal adjustments, especially on a cumulative basis.

The UAE has frontloaded much of the fiscal adjustment and cutback in spending. The pace of subsidy reform in Abu Dhabi and the broadening and raising of government fees have occurred at a steady and staggered pace since early 2015 and early 2018 (with the introduction of VAT). The UAE, with its high hydrocarbon endowment per capita and greater pace of fiscal reform, has one of the strongest fiscal positions among GCC countries, in our view. Moreover, it benefits from the more diversified nature of Dubai's economy, which however was not immune to the fall in the oil price, given the softening in regional demand.

In Saudi Arabia, the pace of reform has been patchier despite announcing a very ambitious fiscal reform program in 2016 for a balanced budget by 2020 , though this target was then extended to 2023 . There have been two main phases of subsidy reforms in Saudi Arabia-(1) end-2015 and January 2016 and (2) January 2018. The impact of the second round of subsidy reforms on Saudi citizens and the introduction of VAT was dampened shortly after, with the introduction of an allowance package for public sector employees. Moreover, the reduction in public sector benefits in Saudi Arabia was short-lived and was reversed. Overall, this still reflects the sensitivity and cautiousness in implementing fiscal reforms that touch Saudi households (Table 9.3).

The other four GCC countries have seen a more moderate pace of fiscal reform, in our focus time period. There have been no major reforms in Qatar since 2017-following the regional developments, the government's focus is on stabilizing and supporting the economy. In Kuwait, there has been substantial populist opposition to fiscal reform, led by the National Assembly. This is the most independent legislature in the GCC and a central stumbling block for the government to make progress with its fiscal reforms. For Bahrain, wider GCC support was vital for the investment program, given the limited fiscal reforms. However, going forward, the pace of fiscal reforms in Bahrain is expected to strengthen for continued GCC support. GCC countries (Kuwait, Saudi Arabia and UAE) pledged USD10 billion in aid to Bahrain in October 2018, significantly reducing short-term funding pressures. The GCC support package will be spread over five years and will be linked to Bahrain's Fiscal Balance Program, which was announced straight after the aid package and aims to balance the budget by 2022 . As noted earlier, VAT was already introduced 
Table 9.3 Components of allowance package, announced on 6 January 2018

Monthly cost of living allowance for one year

- Military and Civil servants

SAR 1000

- Retirement Pension and Social-benefit Recipients

SAR500

Social Security Benefit payment

SAR 500

Student allowance

$10 \%$ increase

VAT covered by government for first home purchase for nationals

Up to

SAR 850,000

VAT covered for private healthcare and education services for nationals

Payment to military personnel serving in Southern border

$-$

SAR5000

Annual Bonus for Military and Civil servants who worked in 2017

Source: Various media sources, cited in $\operatorname{ADCB}(2018,2)$

in 2019 and the 2019 draft budget sees a 12\% drop in government spending in 2019.

The hydrocarbon poorer per capita countries tend to spend more on wages and salaries as a total share of spending, whilst debt servicing costs have also been increasing with rising debt levels. Moreover, with higher GDP per capita in the hydrocarbon richer per capita countries, their populations can more easily absorb fiscal reforms, though it is also of course a function of other factors, including a change in the social contract. The larger expatriate populations relative to domestic populations in the hydrocarbon richer per capita counties also support greater fiscal reforms. On the other hand, the nationals of the relatively hydrocarbon poorer per capita countries are more impacted by the subsidy reforms, resulting in some cases in greater pushback. Moreover, the need for fiscal reform tends to be greater in these countries, though this can be a positive point in ultimately supporting fiscal reforms going forward.

\section{Conclusion}

GCC fiscal reforms have been much wider than seen in previous oil price downturns, with areas that were previously seen as too sensitive to tackle are open to reform and change. GCC countries have implemented a number of reforms since 2014, alongside a deep pullback in government spending - the main earlier method of adjusting to lower oil price. The reduction in subsidies and the introduction of taxes, including for the 
national population, has been significant developments in our view. Despite this, oil income continues to be the main revenue source for GCC government and the need for further reforms to deepen tax revenue remains. Thus, while GCC economies continue to be reliant on hydrocarbon revenue and the social contracts remain, we continue to see hydrocarbon richer per capita countries as being the most sustainable in fiscal terms and in the strongest position to withstand a low oil price backdrop. These governments can better support their national populations.

However, the reforms program has not been uniform, either on a country basis or in a steady implementation of the adjustment period. On a country basis, the UAE and Saudi Arabia have seen the greatest pace of fiscal reforms out of all the GCC countries since 2015-one hydrocarbon richer per capita and one hydrocarbon poorer per capita. This indicates that other economic, social and political factors are important for the ability of regional governments to progress with fiscal reforms beyond the hydrocarbon endowment per capita of countries. However, we believe that hydrocarbon endowment will likely play a strong role, especially in terms of implementing a multi-year reform program. Factors likely contributing include the variations in GDP per capita amongst the national population across the region and their ability to absorb fiscal adjustments, especially on a cumulative basis. Indeed, Saudi Arabia implemented a number of measures to limit the impact of reforms, particularly following the introduction of VAT and subsidy reforms in early 2018. In the case of the UAE, fuel prices have been liberalized and utility prices are likely close to market rates. Most of the UAE's fiscal reforms have had to be absorbed by the economy, with limited measures to dampen the impact of reforms. However, the UAE has generally had to raise prices by a lower magnitude than Saudi Arabia, as they were not so low in absolute terms to start with.

The GCC developments highlight the difficulties in implementing a multi-year fiscal reform program during times of low oil prices, whilst also looking to widen the economic base. This is especially the case when the government has largely remained the main driver of economic activity and domestic demand, either directly through government spending and policy or via government-related entities. The narrow economic (diversification) and private sector base highlights the difficulty in implementing a multi-year fiscal adjustment and austerity program. The fiscal consolidation had led to a sharp slowdown in economic activity, which in turn limits the ability of the economy to absorb new fiscal reforms. In many other regions and countries, fiscal policy is often counter-cyclical to the wider 
economy, whilst, in the GCC, the impact of consolidation is magnified by corporate entities are closely linked to governments and their spending plans. Moreover, with the largely ongoing social contract and the difficulties in the government to increase employment numbers, labor policies are placing additional pressures on the private sectors at times when they are expected to drive growth and support the diversification of the economy.

It remains vital for GCC countries to continue with their fiscal reform programs, to reduce the reliance on the oil sector. Two factors will be central to boosting fiscal sustainability across the region, in our view: (1) the deepening of the tax base and (2) lowering the wage composition of government spending. Hydrocarbon earnings still dominate government revenue and are the main factors driving the overall fiscal position (magnitude of surplus or deficit). GCC tax levels remain low (corporate income tax, individual income tax and VAT) on a MENA and global basis. For some countries, further subsidy reforms are also required. A number of factors will be important for developing the tax base, including reducing the role of the public sector, improving the business climate and a framework for supporting private sector growth. We focus on the issue of labor in our next chapter.

The need to progress with the fiscal reforms is vital, given the ongoing challenges to the oil sector is expected to face, including from improving technology, which will have supply and demand implications. Having a medium- to longer-term fiscal reform program, which progresses at a steady and gradual pace, could help with the implementation. At the same time, wider economic objectives could also be included to improve the sustainability of a fiscal reform framework and raise the capacity of the economies. Focus should also be on targeted measures, spending and investment to support key sectors for diversification, which will be vital in deepening the economy and absorbing further fiscal reforms. Indeed, the earlier period of high government spending growth from the early-2000s did not result in any meaningful economic diversification of the economy and the rise in government spending from 2008 has tended to be on the current side (rather than capital). Measures to attract FDI and strengthen the business environment will also be important. The gradual pace of reform should continue during times of higher oil prices and government spending should be very much targeted towards boosting investment rather than on increasing handouts, though developing an effective social protection framework to support the most vulnerable is important. Greater diversification and further developing the private sector will also be necessary for increasing the employment opportunities for nationals. 


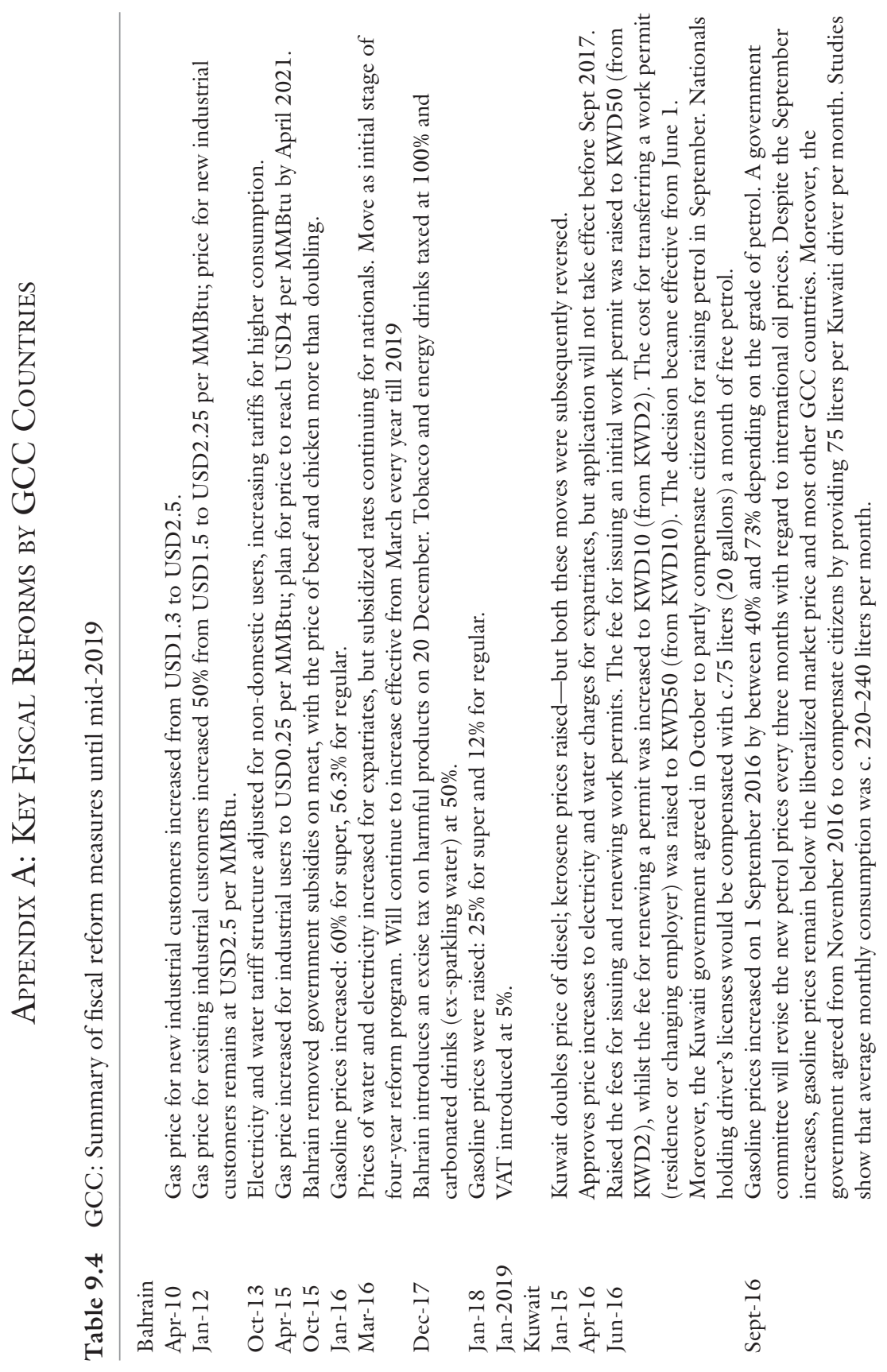




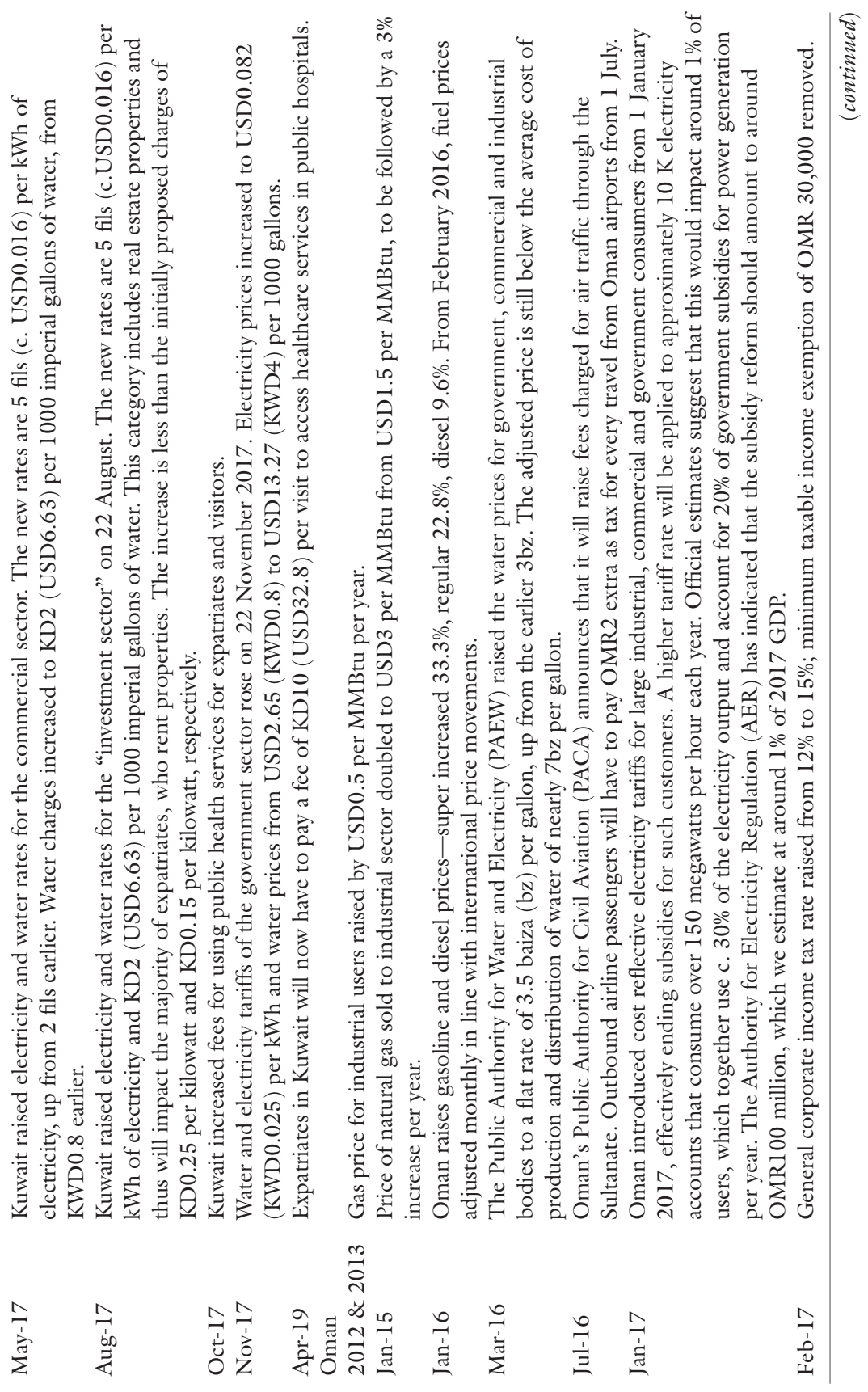




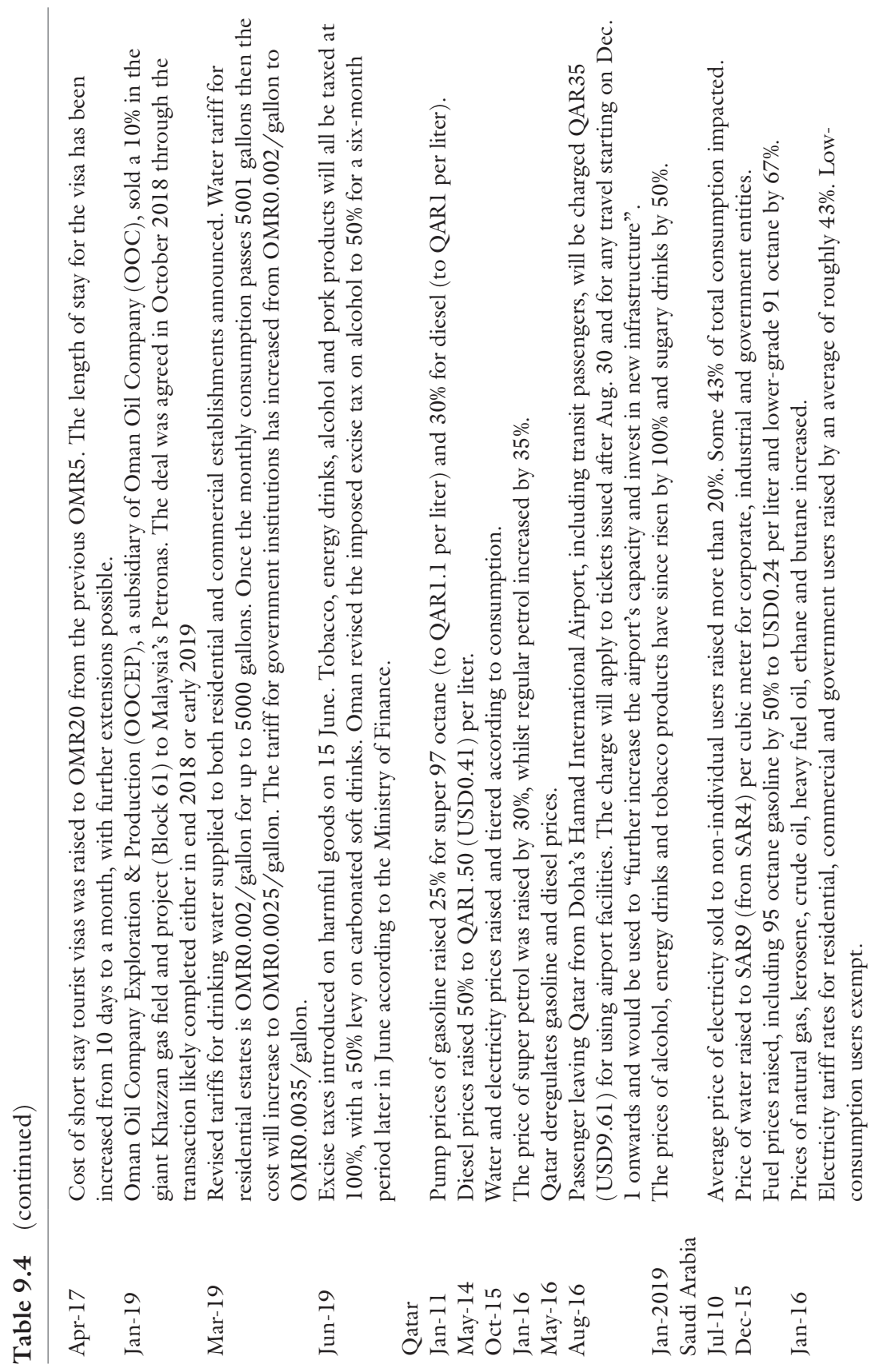




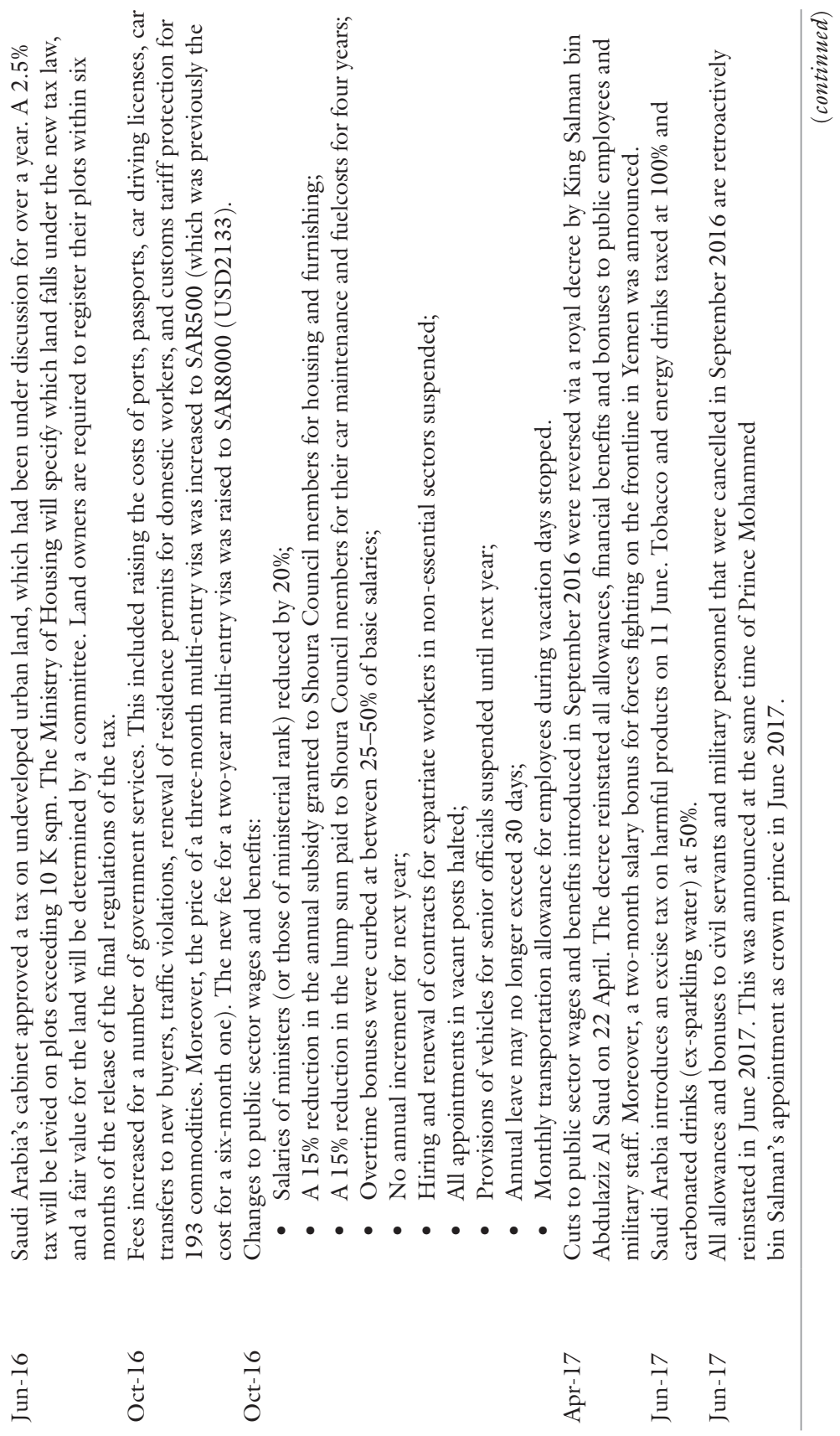




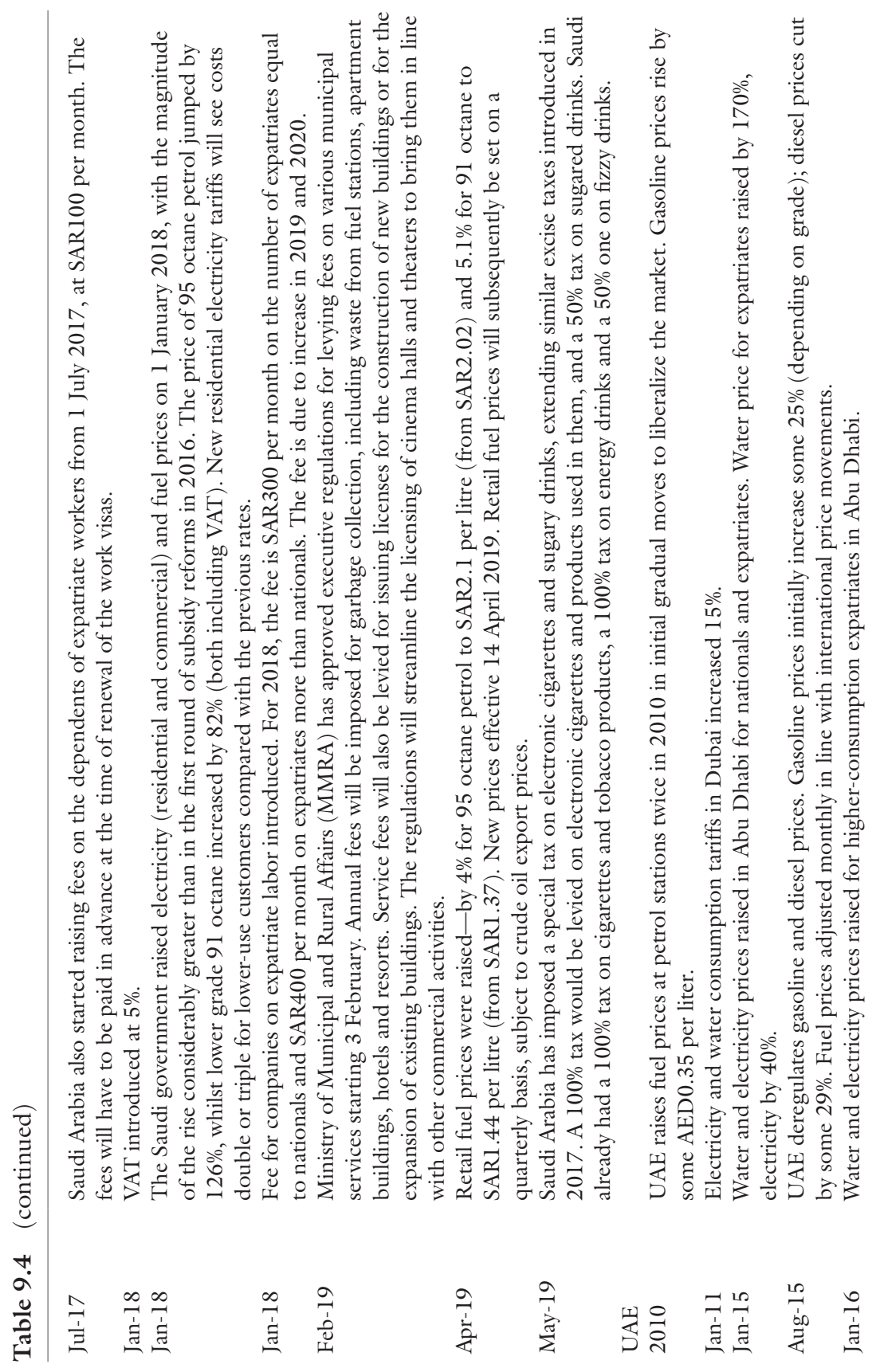


9 FISCAL SUSTAINABILITY AND HYDROCARBON ENDOWMENT PER CAPITA... 247

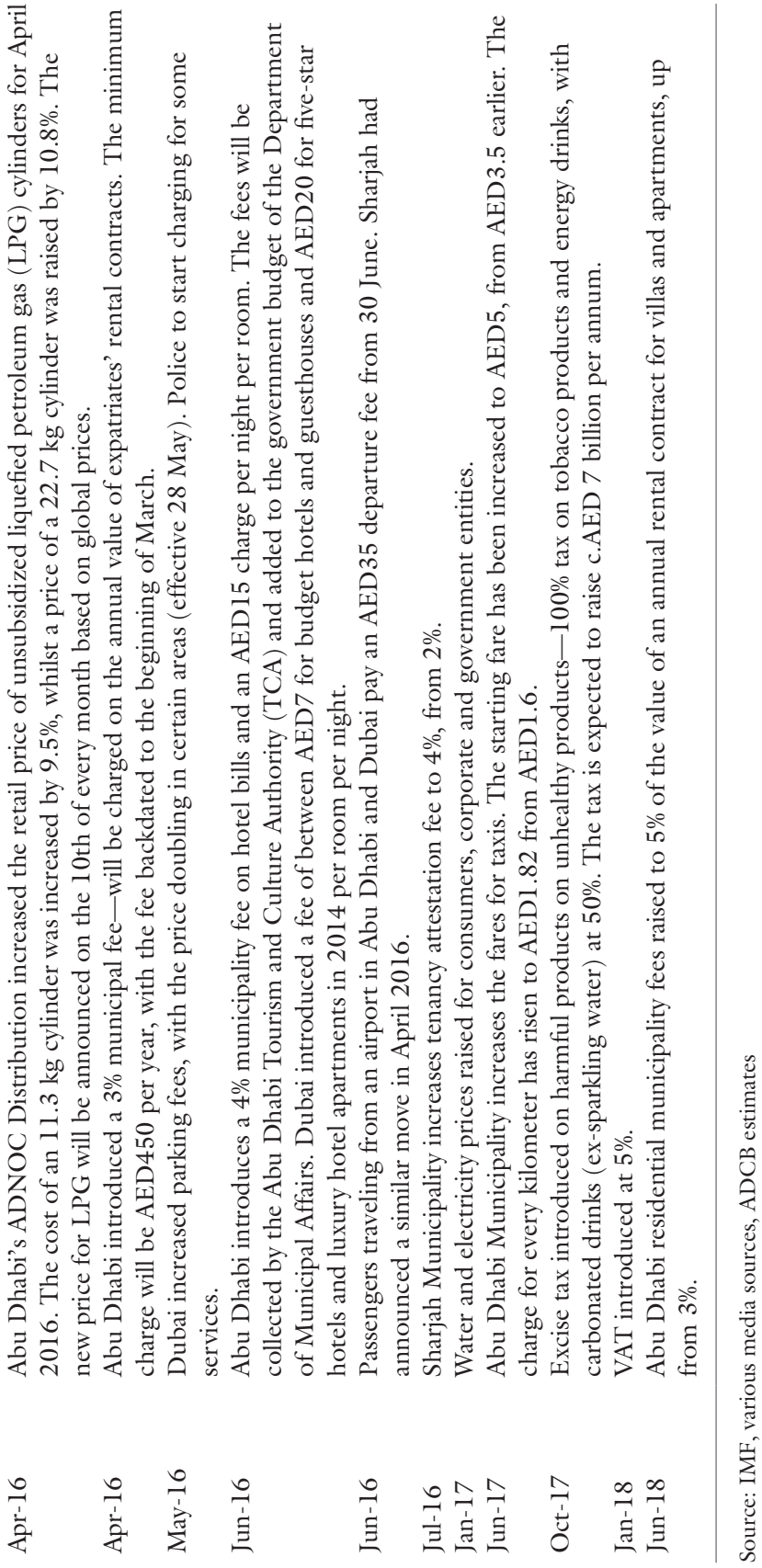




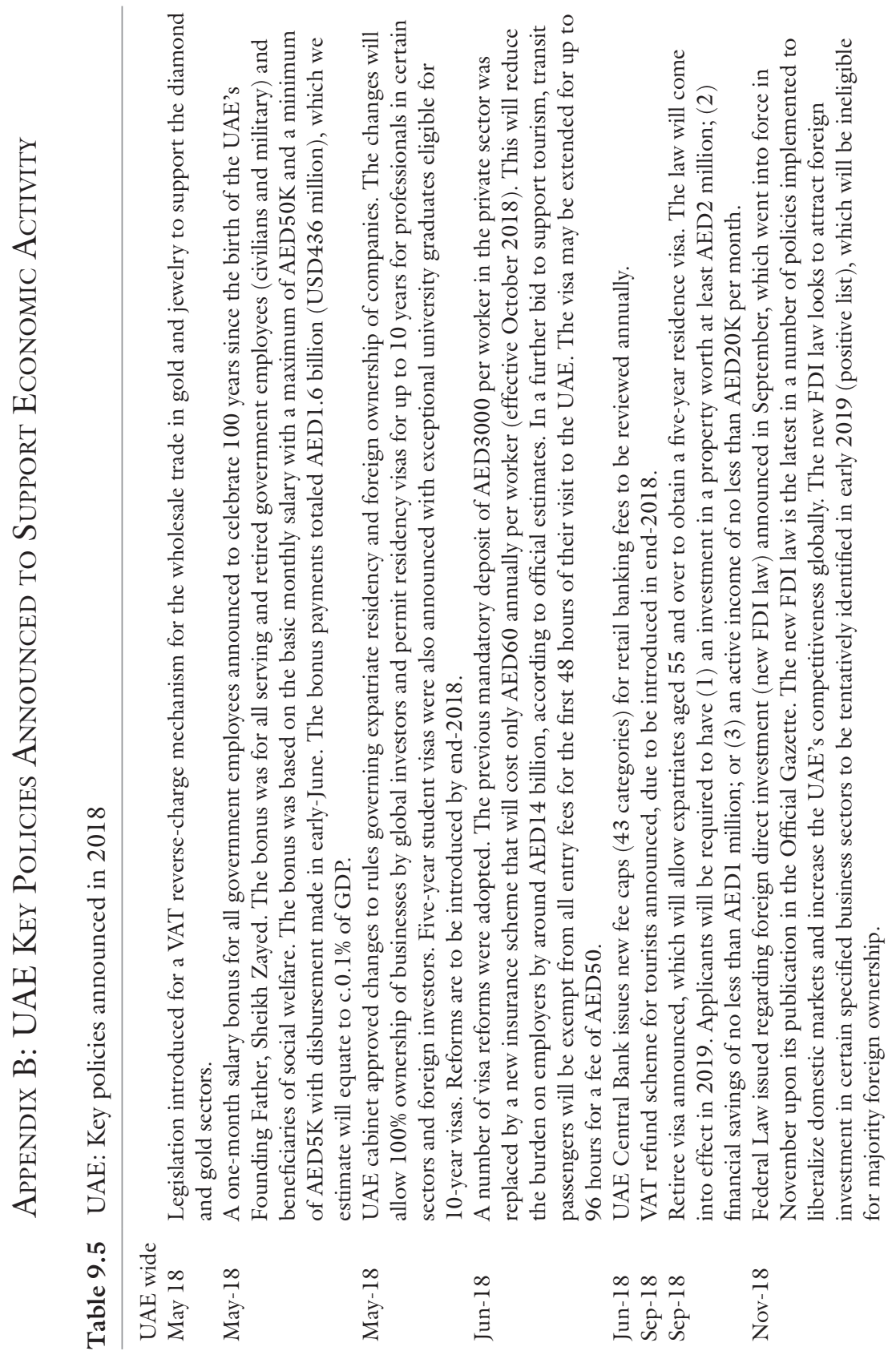




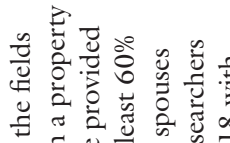

:

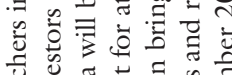

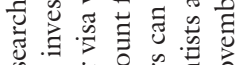

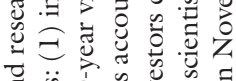

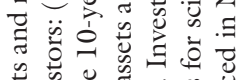

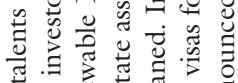

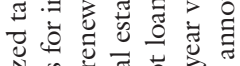

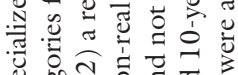

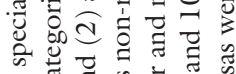

क人

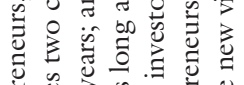

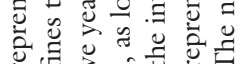

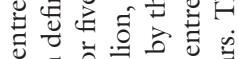

s

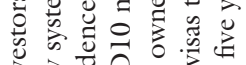

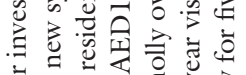

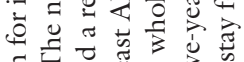

辰

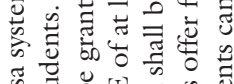

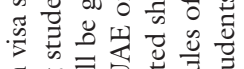

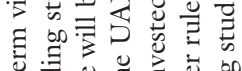

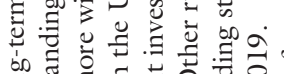

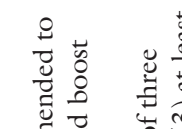

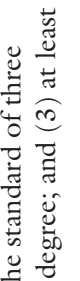

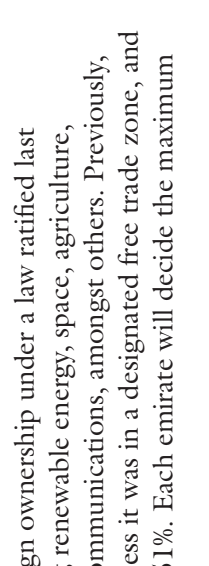

仓ิ

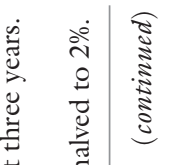

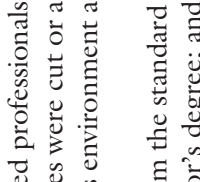

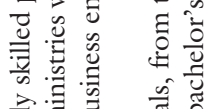

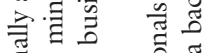

은

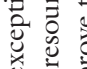

氙苛 苛

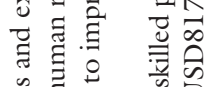

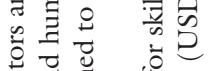

D.

苍名

志空

टे

ฮิ

氙

氙苛余

을

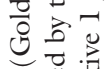

言芯

式芭

छ

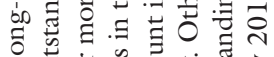

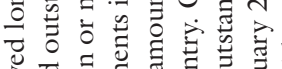

రั0

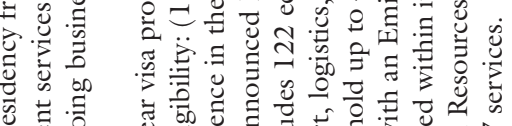

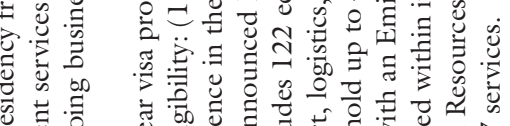

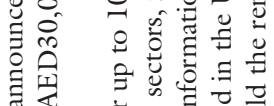

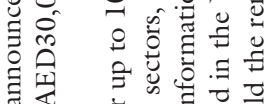

(u)

可

苟華

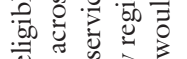

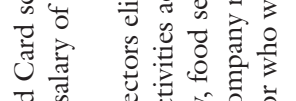

:

苞言

I $\dot{\psi}$

竞总

ป ๙

喝.

क力 更

븡

氙产

के वे

需

$\circ 20$

เิ อี จิ

艺氜

己.

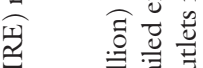

政 寻苞泀

过

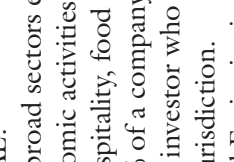

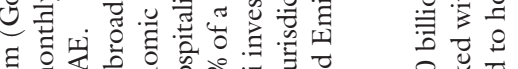

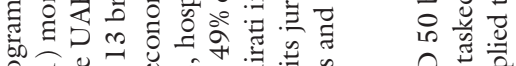

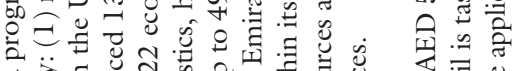

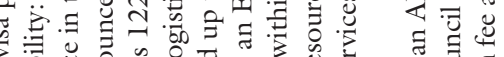

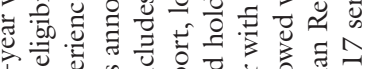

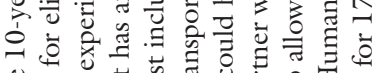

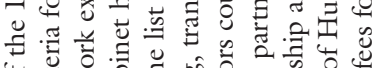

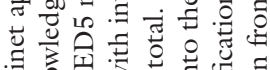

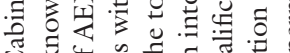

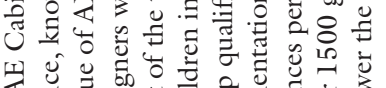

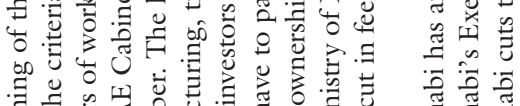

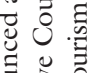

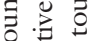

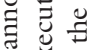

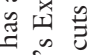

节泀

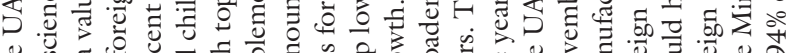

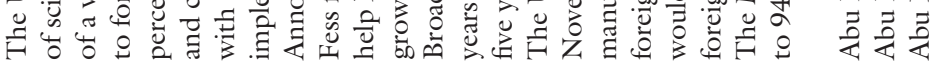
$\stackrel{2}{\stackrel{1}{*}}$
高弯
$\stackrel{\Omega}{\Xi}$
$\stackrel{\Xi}{\Xi}$

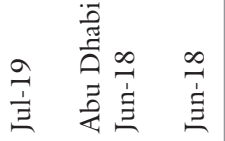




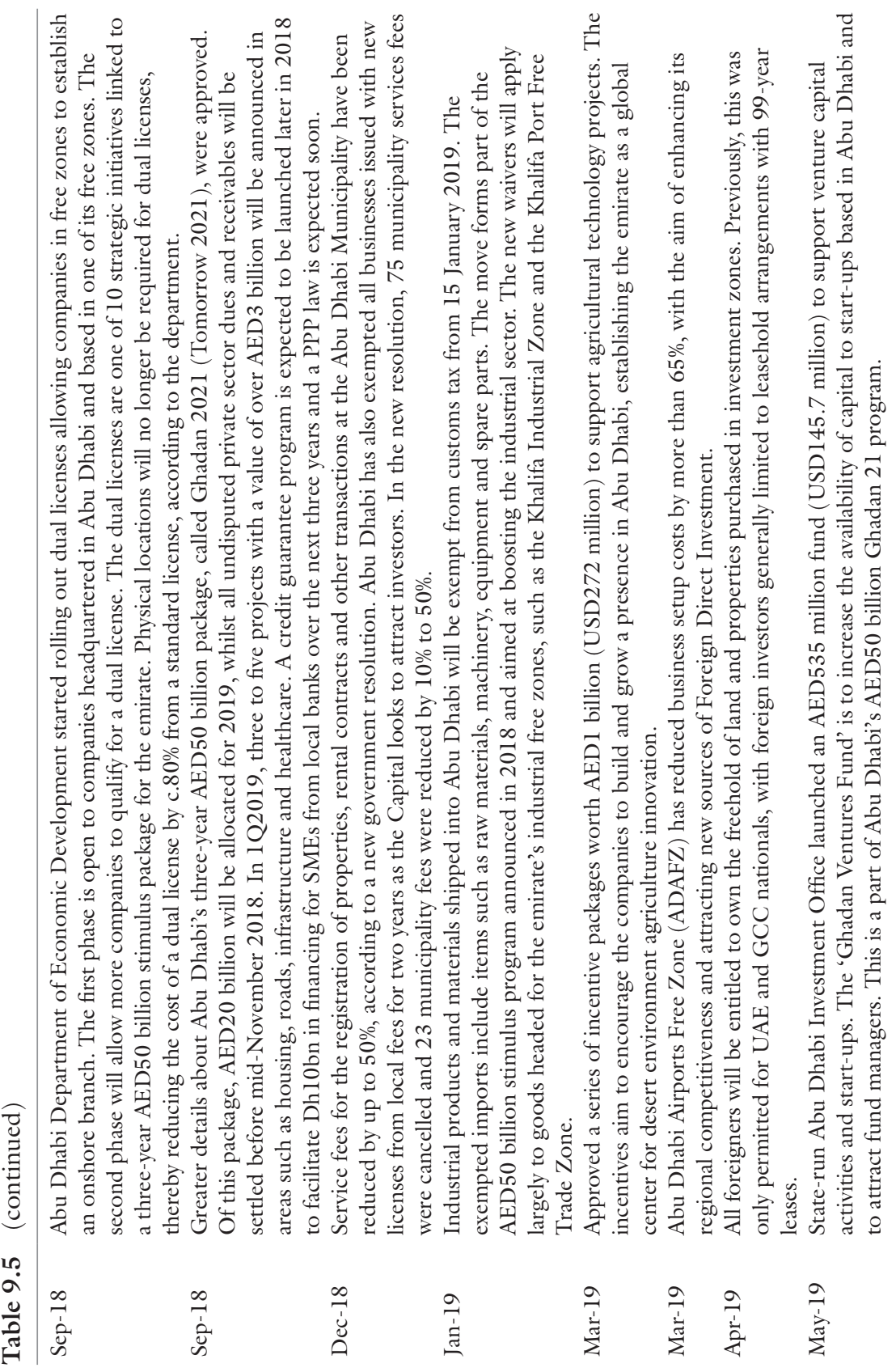




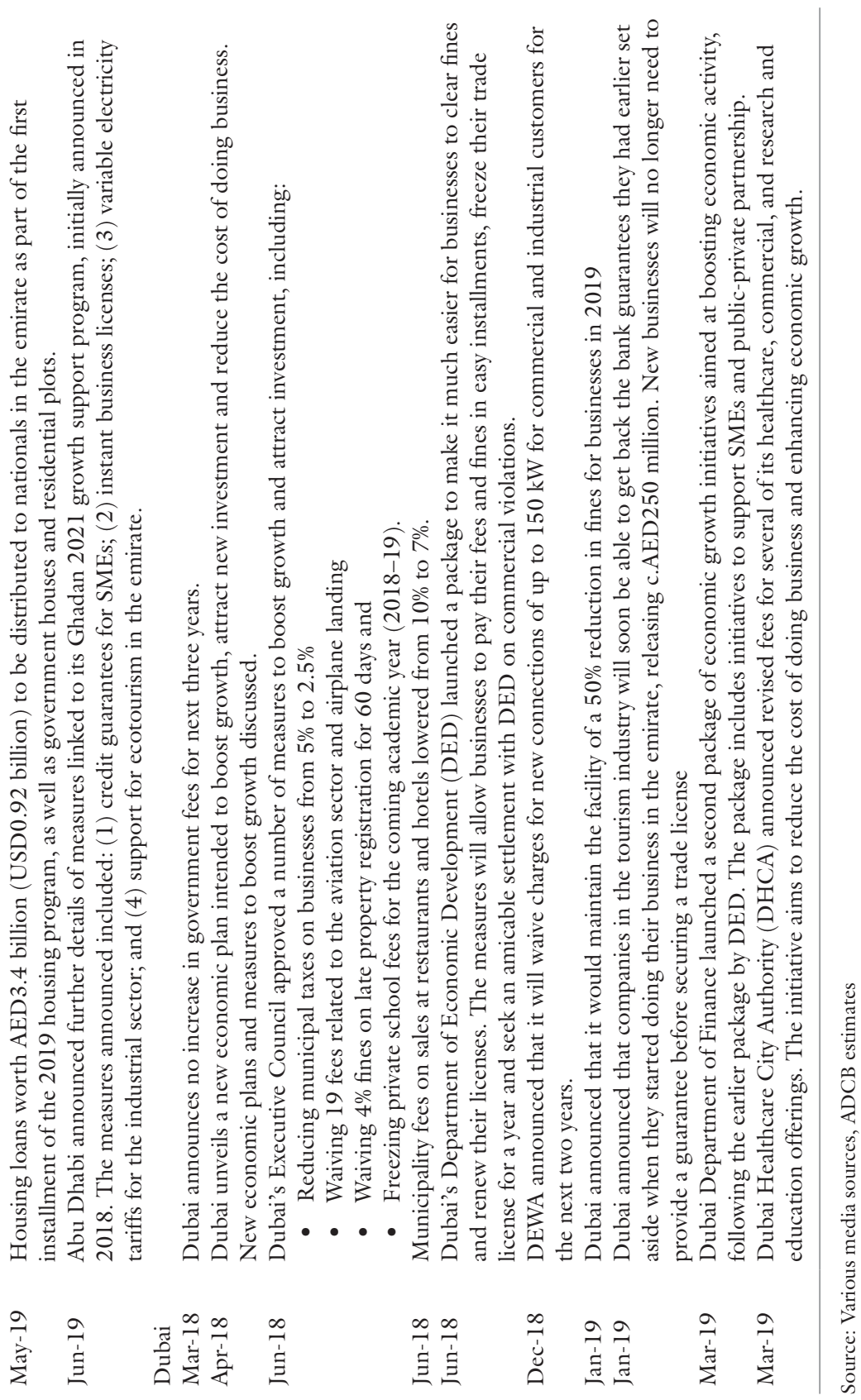




\section{REFERENCES}

ADCB Economic Research. 2017. GCC Economic Update - Assessing the economic impact of VAT. (Published on 14 June 2017, authors Monica Malik and Shailesh Jha).

ADCB Economic Research. 2018. Oman Economic Update - Previous investment paying dividends and boosting export capacity. (Published on 3 September 2018, authors Monica Malik and Thirumalai Nagesh).

ADCB Economic Research. 2019. GCC Economic Update - Fragile non-oil growth recovery with limited pick-up in momentum. (Published on 13 February 2019, authors Monica Malik and Thirumalai Nagesh).

Bloomberg. 2018. Odd One Out? Kuwait Is Struggling to Pass VAT Agreed by Gulf (published 10 May 2018, authors Fiona MacDonald and Zainab Fattah).

IMF. 2016. Diversifying Government Revenue in the GCC: Next Steps. (Date 26 October 2016) https://www.imf.org/external/np/pp/ eng/2016/102616.pdf.

Institute of International Finance. 2018. Hydrocarbon Exporters Breakeven Oil Prices have declined. (Published on 1 February 2018, authors Garbis Iradian and Boban Markovic).

Kingdom of Saudi Arabia, Ministry of Finance. 2016a. 2017 Budget. https:// www.mof.gov.sa/en/financialreport/budget2017/Documents/The_ National_Budget.pdf.

Kingdom of Saudi Arabia. 2016b. Fiscal Balance Program, Balanced Budget 2020. https://vision2030.gov.sa/en/bb2020.

Kingdom of Saudi Arabia. 2017. Fiscal Balance Program, 2018 Update. https:// vision2030.gov.sa/en/bb2020.

Reuters. 2019. Oman to delay VAT to 2021 amid sluggish growth (published 30 July 2019, author Davide Barbuscia) https://www.reuters.com/article/us-oman-economy-vat/oman-to-delay-vat-to-202l-amid-sluggish-growth-idUSKCNIUPITM. 
Open Access This chapter is licensed under the terms of the Creative Commons Attribution-NonCommercial-NoDerivatives 4.0 International License (http:// creativecommons.org/licenses/by-nc-nd/4.0/), which permits any noncommercial use, sharing, distribution and reproduction in any medium or format, as long as you give appropriate credit to the original author(s) and the source, provide a link to the Creative Commons licence and indicate if you modified the licensed material. You do not have permission under this licence to share adapted material derived from this chapter or parts of it.

The images or other third party material in this chapter are included in the chapter's Creative Commons licence, unless indicated otherwise in a credit line to the material. If material is not included in the chapter's Creative Commons licence and your intended use is not permitted by statutory regulation or exceeds the permitted use, you will need to obtain permission directly from the copyright holder. 